\section{Integration into the Labor Market of Young Students from the "Stefan cel Mare" University of Suceava}

\section{Alexandra TERLEKI ${ }^{1}$}

${ }^{1}$ Stefan cel Mare University from Suceava, Romania.
Abstract: A real problem for students is to integrate into the field of work, either due to the lack of a job that corresponds to the student's expectations or knowledge, or because of the large number of candidates for a particular vacancy or lack of experience required by the employer. The present research aims at analyzing the degree of satisfaction of the students enrolled at "Stefan cel Mare" University of Suceava regarding the way they integrate into the labor market. The main objective of this research was to identify and analyze the number of students in the "Ştefan cel Mare" University in Suceava who are employed or who have a job and also what motivations or what they have determined some of them to engage. The data suggest that students who wanted to work were faced with the employer's refusal to hire them because they did not gain the necessary experience for the job. Students who have started working early have, therefore, an advantage in finding a convenient job after completing their studies, compared to those who have not yet had an employment contract. It is worth noting that today's students are adept at finding employment opportunities online, where they get information on vacancies so that the press or newspaper ads are no longer in the students' interest. Also, Employment Agencies have been replaced by ads through their close friends, friends or acquaintances.

Keywords: Labor market; graduates; socio-professional integration;

How to cite: Terleki, A. (2018). Integration into the Labor Market of Young Students from the "Stefan cel Mare" University of Suceava. Moldavian Journal for Education and Social Psychology, 2(1), 77-112. https://doi.org/10.18662/mjesp/04 


\section{Introducere}

O reală problemă a studenților este aceea de a se integra în câmpul munciii, fie datorită lipsei unui loc de muncă care să corespundă aşteptărilor sau cunoştinţelor studentului, fie a existenței unui număr mare de doritori a unui anumit post vacant, fie a lipsei de experiență cerută de angajator tinerilor.
Abrevieri
F LITERE - Facultatea de Litere şi Ştiințe ale Comunicării
F SILVIC - Facultatea de Silvicultură
FDSA - Facultatea de Drept şi Ştiinţe Administrative
FEFS - Facultatea de Educație Fizică şi Sport
FIA - Facultatea de Inginerie Alimentară
FIESC - Facultatea de Inginerie Electrică şi Ştiința Calculatoarelor
FIG - Facultatea de Istorie şi Geografie
FIM - Facultatea de Inginerie Mecanică, Mecatronică şi Management
FSEAP - Facultatea de Ştiinţe Economice şi Administraţie Publică
FSED - Facultatea de Ştiinţe ale Educației
USV - Universitatea „SStefan cel Mare” din Suceava

\section{Scopul şi obiectivele cercetării}

Cercetarea de față are drept scop analizarea gradului de mulţumire al studenților înscrişi la Universitatea „Ştefan cel Mare” din Suceava privind modul în care se integrează aceştia pe piața muncii.

Prin urmare, pentru a reuşi să atingem scopul propus, a fost necesară parcurgerea următoarelor etape:

- realizarea unui chestionar prin care să putem cere părerea unui număr cât mai mare de studenți în ceea ce priveşte modul în care reuşesc tinerii să se integreze pe piața muncii;

- elaborarea unei baze de date obținute în urma centralizării rezultatelor din chestionar, pe care le vom interpreta ulterior în scopul obținerii unei concluzii generale privind cariera profesională a studenților.

Obiectivul principal al acestei cercetări a fost identificarea şi analiza numărului de studenți din cadrul Universităţii „Ştefan cel Mare” din Suceava care sunt angajaţi sau care au avut un loc de muncă şi, de asemenea, care au fost motivațiile sau ce anume i-a determinat pe o parte dintre aceştia să se angajeze.

În al doilea rând, am fost interesați să aflăm cât de uşor sau dificil le-a fost studenților să reuşească să se poziționeze pe piața muncii, dacă locul de 
muncă ocupat corespunde cu aşteptările avute şi care este părerea lor legată de disponibilitatea locurilor de muncă din județul Suceava. De asemenea, considerăm necesar să identificăm şi numărul studenților care vor opta pentru un loc de muncă în țară sau în străinătate, dar şi părerea acestora legată de acest subiect.

\section{Metodologia de cercetare}

În această parte a studiului vom prezenta metodele folosite în această cercetare ştiințifică, metode care se referă la descrierea eşantionului şi a unităţii de învățământ cercetate, metoda prin care au fost culese informațiile, dar şi stabilirea coordonatelor spațiale şi temporale.

\section{Descrierea colectivității şi a unităţii de învăţământ cercetate}

Colectivitatea analizată este reprezentată de totalitatea studenților înscrişi în cadrul programului de licenţă al Universităţii „Ştefan cel Mare” din Suceava.

Eşantionul este alcătuit de 100 de persoane, studenți ai programului de licență, din facultăți, ani de studiu şi forme de învăţământ diferite, pentru a asigura un eşantion cât mai diversificat.

Datorită faptului că mărimea eşantionului are ca număr 100 de subiecți, rezultă că cercetarea noastră nu este una de mari dimensiuni.

Având în vedere că universitatea a înregistrat în anul 2017 un număr de 5095 de studenți, iar această cercetare a cuprins doar 100 dintre aceştia, nu ne propunem ca rezultatele înregistrate să aibă o probabilitate absolută, ci doar un caracter orientativ. În acest sens, am considerat necesar calcularea marjei de eroare a cercetării, care s-a dovedit a avea o variație maximă admisă de $+/-9 \%$. ${ }^{1}$

Studenții participanți la acest studiu au fost împărțiţi după diverse criterii, fie în funcție de mediul de proveniență, fie după gen, sau după categoria de vârstă. Datorită diferitelor caracteristici regăsite la fiecare întrebare la care studenții au răspuns, am obținut în final rezultate concrete şi complexe, astfel metoda dovedindu-se a fi una eficientă.

În ceea ce priveşte mediul de proveniență al subiecților, în urma datelor obținute prin aplicarea chestionarului se pot constata următoarele rezultate:

\footnotetext{
1 Valoarea marjei de eroare al eșantionului INFOmass, disponibil la adresa:www.infomass.ro/resurse/calculator -eroare-esantion/.
} 
Tabelul nr. 1. Mediul respondenților

\begin{tabular}{|l|l|c|}
\hline 1. & Mediul de proveniență & $\mathbf{1 0 0} \%$ \\
\hline & Urban & $45 \%$ \\
\hline & Rural & $55 \%$ \\
\hline & TOTAL & $100 \%$ \\
\hline
\end{tabular}

Sursa: Date obținute în urma centralizării rezultatelor pe baza chestionarului aplicat on-line la adresa https://docs.google.com/forms/u/0/

Prin urmare, constatăm o distribuție relativ echilibrată între cele două tipuri de medii. Assa cum putem vedea în tabelul numărul 1, cei din mediul rural au pocent uşor mai ridicat, de $55 \%$, iar cei din mediul urban o pondere de $45 \%$. Pentru a putea reprezenta mai vizibil aceste date, am realizat graficul numărul 1.

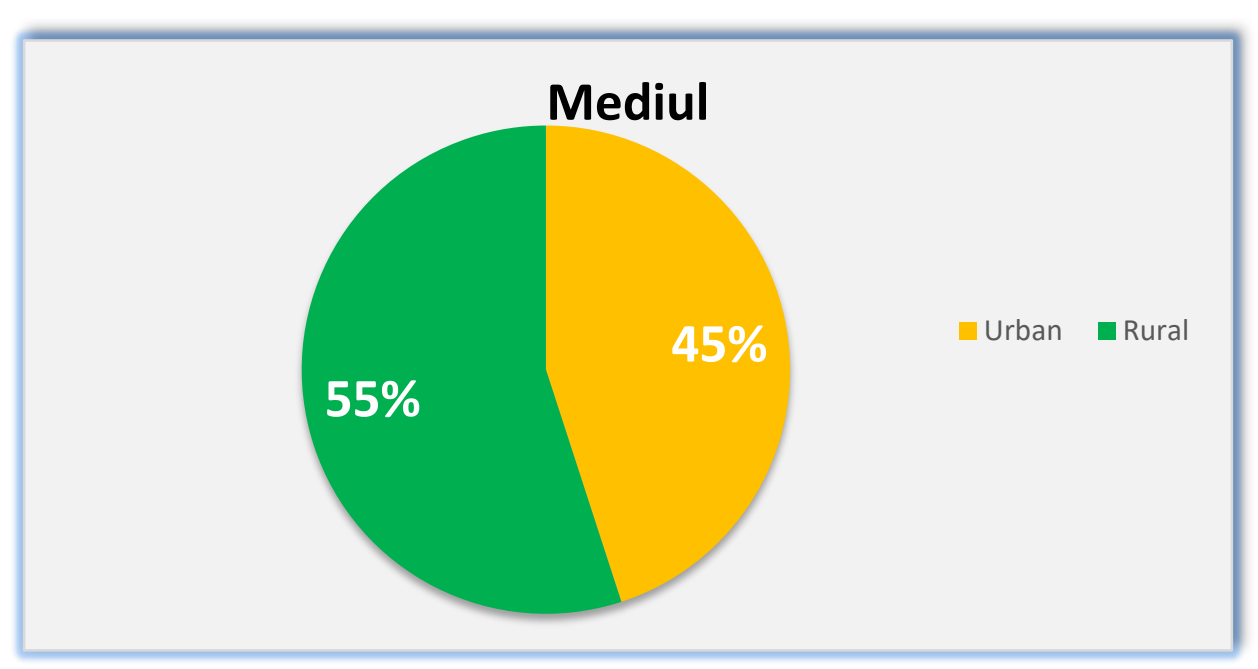

Graficul nr.1. Mediul respondenților

Sursa: Date obținute în urma centralizării rezultatelor pe baza chestionarului aplicat on-line la adresa https://docs.google.com/forms/u/0/

Referitor la genul respondenților se constată următoarele rezultate: 
Integration into the Labor Market of Young Students from the "Stefan cel Mare" ... Alexandra TERLEKI

Tabelul nr.2. Genul respondenților

\begin{tabular}{|c|l|c|}
\hline 2. & Genul & $\mathbf{1 0 0} \%$ \\
\hline & Masculin & $26 \%$ \\
\hline & Feminin & $74 \%$ \\
\hline & TOTAL & $100 \%$ \\
\hline
\end{tabular}

Sursa: Date obținute în urma centralizării rezultatelor pe baza chestionarului aplicat on-line la adresa https://docs.google.com/forms/u/0/

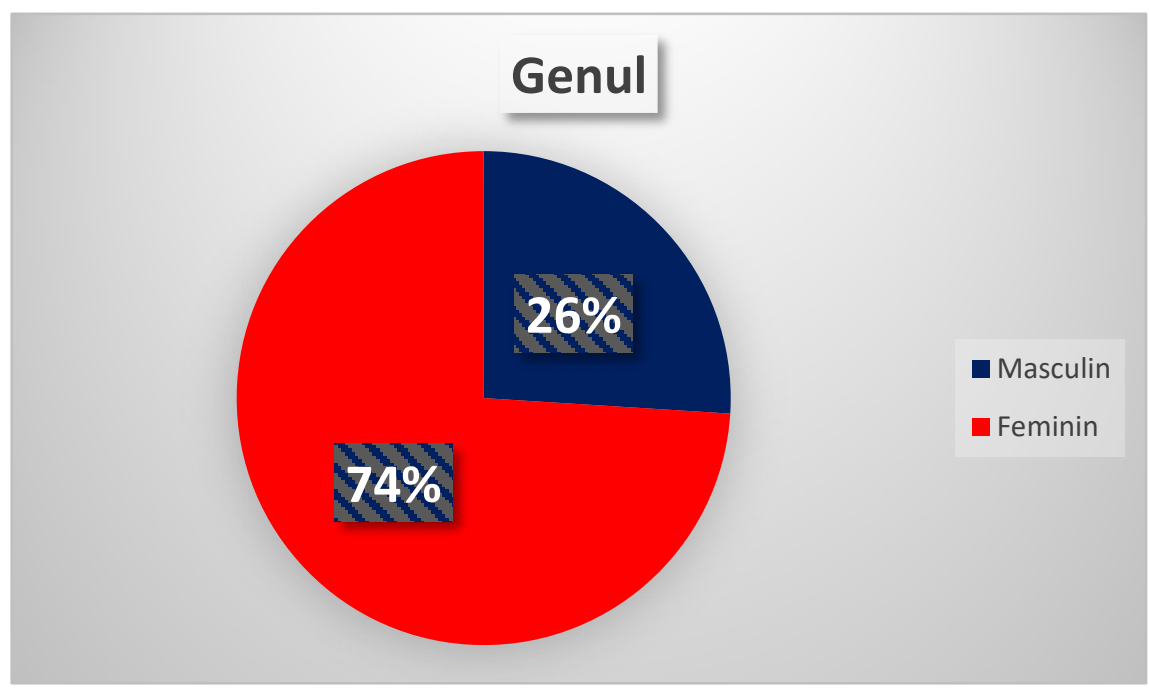

Graficul nr.2. Genul subiecților

Sursa: Date obținute în urma centralizării rezultatelor pe baza chestionarului aplicat on-line la adresa https://docs.google.com/forms/u/0/

Chestionarul respectă distribuția generală pe sexe, la nivel național potrivit graficului nr. 2. După centralizarea răspunsurilor în ceea ce priveşte genul respondenților, putem constata o diferență vizibilă între cele două tipuri de respondenți, în sensul că majoritatea persoanelor din grupul analizat sunt de gen feminin, într-un procent de $74 \%$, iar subiecții de genul masculin formează un procent de numai $26 \%$.

Pentru a avea informații despre categoria respondenților la această cercetare am considerat relevant să aflăm vârsta acestora. 
Tabelul nr. 3. Vârsta respondenților

\begin{tabular}{|l|l|c|}
\hline 3. & Vârsta & $\mathbf{1 0 0} \%$ \\
\hline & Sub 20 de ani & $15 \%$ \\
\hline & $20-25$ de ani & $74 \%$ \\
\hline & Peste 25 de ani & $11 \%$ \\
\hline & TOTAL & $100 \%$ \\
\hline
\end{tabular}

Sursa: Date obținute în urma centralizării rezultatelor pe baza chestionarului aplicat on-line la adresa https://docs.google.com/forms/u/0/

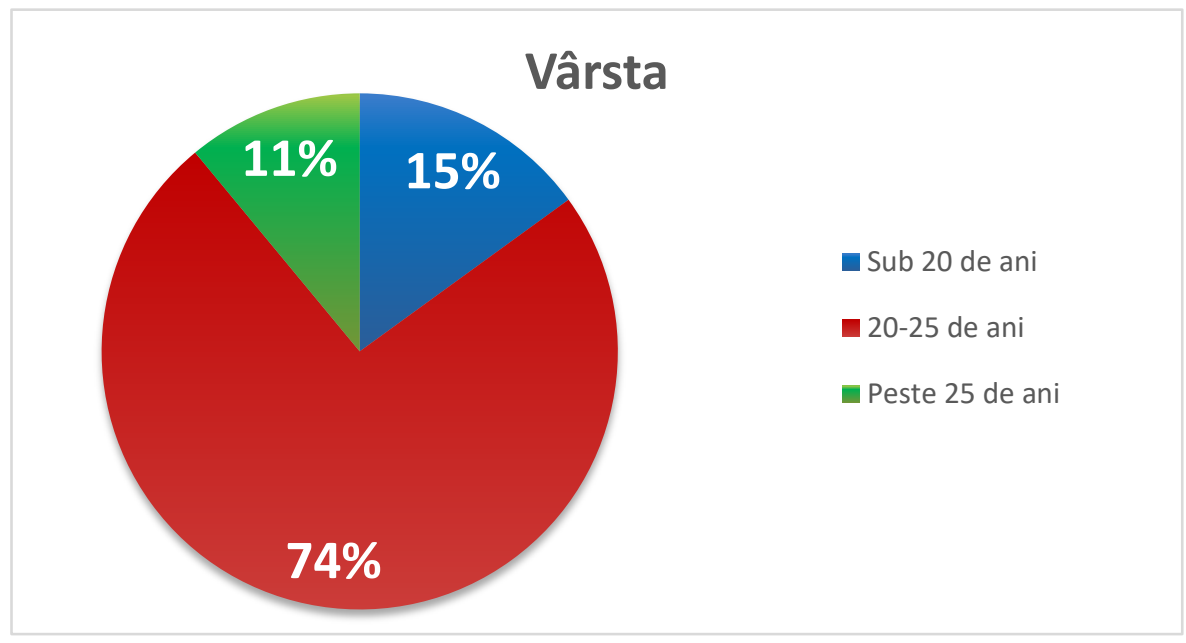

Graficul nr. 3. Vârsta respondenților

Sursa: Date obținute în urma centralizării rezultatelor pe baza chestionarului aplicat on-line la adresa https://docs.google.com/forms/u/0/

Tinerii sub 20 de ani reprezintă $15 \%$ din eşantion, cei cu vârste cuprinse între 20 şi 25 de ani $44 \%$, iar cei peste 25 de ani $11 \%$. Cel mai bine reprezentat este grupul persoanelor care au între 20 şi 25 de ani, având şi cea mai mare pondere $(74 \%)$, urmând cei sub 20 de ani, cu un procent scăzut $(15 \%)$, iar apoi cei peste 25 de ani, care şi-au arătat cel mai puțin disponibilitatea de a participa la tema propusă. Ceea ce ne bucură este faptul că un număr mare de tineri cu vârstele cuprinse între 20 şi 25 de ani s-au implicat şi au furnizat date relevante la întrebările chestionarului.

În ceea ce priveşte unitatea de învăţământ din care fac parte respondenții, în continuare am realizat o scurtă descriere a acesteia. 
Integration into the Labor Market of Young Students from the "Stefan cel Mare" ... Alexandra TERLEKI

Universitatea „SStefan cel Mare” este o instituție de învăţământ superior, care îşi propune să ofere studențlor săi atât o calificare superioară, cât şi competențele reale pentru a-şi putea dezvolta o carieră de succes în viitor.

„Universitatea dispune de 55 de programe de studii de licenţă (dintre care 46 de programe de studii sunt cu frecvență (IF), iar 9 programe de învățământ la distanță (ID)), 11 programe de conversie profesională şi 49 de programe de studii universitare de master" (USV, 2017).

De asemenea, Universitatea „Ștefan cel Mare" are în componența programului de licenţă 10 facultăţi: Inginerie Electrică şi Ştiinţa Calculatoarelor; Inginerie Mecanică, Mecatronică şi Management; Educaţie Fizică şi Sport; Inginerie Alimentară; Istorie şi Geografie; Litere şi Ştiinţe ale Comunicării; Silvicultură; Ştiințe Economice şi Administraţie Publică; Ştiințe ale Educaţiei; Drept şi Ştiințe Administrative (USV, 2017).

Prin urmare, am realizat tabelul nr. 4, în care am prezentat distribuția studenților participanți la cercetare în cadrul fiecărei facultăți a pogramului de licență din universitate.

Tabelul nr. 4. Facultatea respondenților

\begin{tabular}{|c|c|c|}
\hline 4. & Facultatea & $100 \%$ \\
\hline & $\begin{array}{l}\text { „Facultatea de Inginerie Electrică şi Ştiința } \\
\text { Calculatoarelor” }\end{array}$ & $7 \%$ \\
\hline & $\begin{array}{l}\text { „Facultatea de Inginerie Mecanică, Mecatronică şi } \\
\text { Management” }\end{array}$ & $2 \%$ \\
\hline & „Facultatea de Educație Fizică şi Sport” & $11 \%$ \\
\hline & „Facultatea de Inginerie Alimentară” & $9 \%$ \\
\hline & „Facultatea de Istorie şi Geografie” & $7 \%$ \\
\hline & „Facultatea de Litere şi Ştiințe ale Comunicării” & $11 \%$ \\
\hline & „Facultatea de Silvicultură” & $4 \%$ \\
\hline & $\begin{array}{l}\text { „Facultatea de Ştiințe Economice şi Administrație } \\
\text { Publică” }\end{array}$ & $39 \%$ \\
\hline & „Facultatea de Ştiințe ale Educație”” & $3 \%$ \\
\hline & „Facultatea de Drept şi Ştiințe Administrative” & $7 \%$ \\
\hline & TOTAL & $100 \%$ \\
\hline
\end{tabular}

Sursa: Date obținute în urma centralizării rezultatelor pe baza chestionarului aplicat on-line la adresa https://docs.google.com/forms/u/0/ 


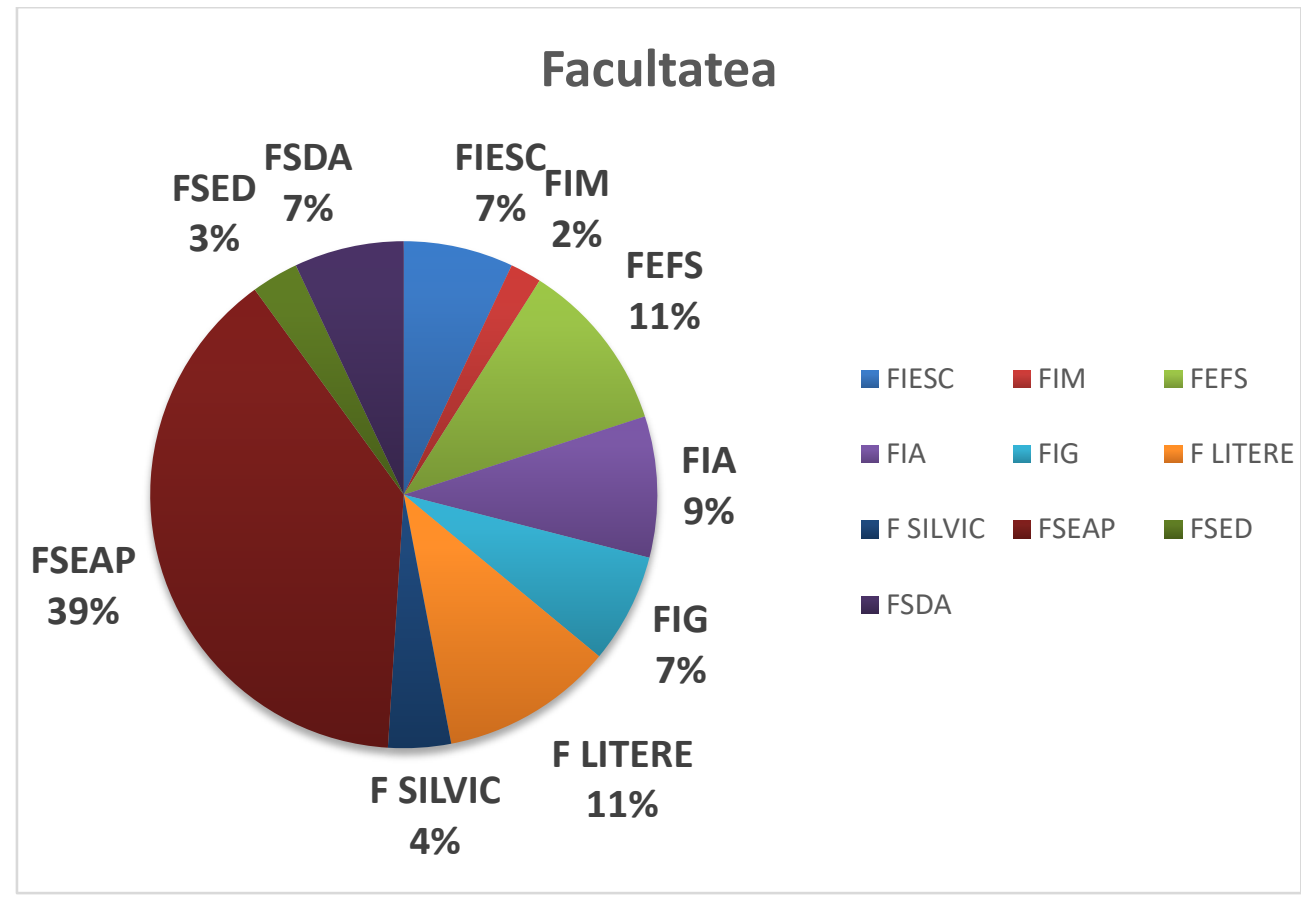

Graficul nr. 4. Facultatea respondenților

Sursa: Date obținute în urma centralizării rezultatelor pe baza chestionarului aplicat on-line la adresa https://docs.google.com/forms/u/0/

Conform graficului numărul 4, putem vedea concret numărul celor care au răspuns la chestionar în cadrul fiecărei facultăţi. Aici am reusit să cuprindem cel puţin câte un subiect din fiecare categorie, majoritatea acestora fiind înmatriculată la „Facultatea de Ştiinţe Economice şi Administraţie Publică”, în procent de 39\%. Pe locul doi ca pondere a răspunsurilor se află studenţii de la „Facultatea de Litere şi Ştiinţe ale Comunicării” şi „Facultatea de Educaţie Fizică şi Sport”, în acelaşi procent de 11\%, mai apoi „Facultatea de Inginerie Alimentară", cu 9\%, urmând cu procente mai mici, de 7\%, 4\%,3\%, Şi $2 \%$, celelalte facultăţi. Nu am putut stabili o proporţionalitate echilibrată între numărul de studenţi de la fiecare facultate datorită faptului că am aplicat un chestionar online, fapt care a înregistrat ponderi mai mari la o facultate faţă de alta. Indiferent de facultatea de la care fac parte studenţii, se remarcă disponibilitatea şi interesul studenţilor în parcurgerea întrebărilor. 


\section{Stabilirea instrumentului de colectare a datelor}

Una dintre cele mai eficiente metode care afăcut posibilă realizarea acestei cercetări şi a ajutat la colectarea datelor este chestionarul. Acest instrument de bază al cercetării noastre face realizabilă colectarea unor informații despre subiecți, urmărind totodată comportamentul acestora, dar şi obținerea unui feedback real.

Chestionarul realizat şi analizat în această cercetare cuprinde o parte introductivă, care descrie obiectivul şi scopul cercetării, participanții fiind informați asupra scopului şi obiectivului cercetării, a confidențialităţii răspunsurilor, asupra modului în care vor fi prelucrate datele, dar şi asupra duratei medii de completare a chestionarului (7-10 minute), participarea la studiu fiind voluntară.

Acesta cuprinde 24 de întrebări, dintre care 20 vizează variante de întrebări închise, iar 4 sunt întrebări semi-deschise, la care respondenții au şansa de a de răspunde avansând propria variantă, alta decât cele deja existente în chestionar. Există şi un set de 4 întrebări la care respondenții, dacă consideră necesar, pot alege mai multe variante de răspuns la o singură întrebare. De asemenea, aceştia au şi posibilitatea de a nu da un răspuns concret, bifând varianta neutră „Nu ştiu/Nu răspund”.

La începutul chestionarului am considerat important introducerea unor întrebări personale, pentru a afla câteva caracteristici ale subiecţilor care manifestă un interes direct în cercetarea noastră, întrebări care fac referire la: mediul de proveniență, genul subiecților, vârsta şi facultatea de la care provin. Apoi întrebările se referă la corelaţia dintre universitate şi locul de muncă, la aspectele ce țin de căutarea unui loc de muncă, încheindu-se cu întrebări ce vizează părerea studenților despre gradul de satisfacție pe care îl oferă piaţa forței de muncă a județului Suceava..

\section{Stabilirea reperelor temporale şi spațiale ale cercetării}

Datele pe care le explorăm în această cercetare au fost culese în urma aplicării unui chestionar în perioada 18.02.2018-5.04.2018, în campusul Universității „SStefan cel Mare” din Suceava.

Cercetarea constă în aplicarea unui chestionar care se completează online, conținând în mare parte întrebări închise, la care se răspunde prin bifarea căsuței dorite, dar şi răspunsuri semi-deschise, numite sub forma „Altă variantă", la care participantul poate răspunde completând cu răspunsul dorit.

Distribuția s-a făcut în campusul universităţii prin transmiterea directă a unei adrese web studentului respectiv ("Chestionar privind", 2018). Desigur, acest lucru poate constitui o sursă de eroare pentru rezultatele cercetării, 
deoarece nu toți studenţii universităţii au avut acces la completarea chestioarului.

În momentul de față datele colectate prezintă în principal interes ca element de noutate, deoarece dimensiunea cercetării şi timpul necesar realizării au fost prea scurte pentru a putea realiza o cercetare relevantă şi pe o durată mare de timp.

\section{Rezultatele cercetării}

Primele 4 întrebări, referitoare la datele de intentificare ale respondenților, au fost centralizate şi prelucrate în subcapitolul anterior, astfel că în continuare vom începe prezentarea datelor colectate la întrebările specifice temei abordate.

Pentru a putea afla care a fost motivația fiecărui student în alegerea facultăţii şi programului de studiu, am iniţiat întrebarea referitoare la utilitatea programului de licenţă.

Tabelul nr. 5. Utilitatea programului de licenţă

\begin{tabular}{|c|l|c|}
\hline 5. & $\begin{array}{l}\text { Cum credeți că vă va ajuta pe viitor programul de } \\
\text { licență ales?* }\end{array}$ & \\
\hline & Pentru a obține un loc de muncă & $54 \%$ \\
\hline & Pentru dezvoltarea în carieră pe termen lung & $37 \%$ \\
\hline & $\begin{array}{c}\text { Pentru îndeplinirea sarcinilor de la locul meu de muncă } \\
\text { actual sau din viitor }\end{array}$ & $8 \%$ \\
\hline & Pentru îndeplinirea obligațiilor din viața de zi cu zi & $7 \%$ \\
\hline & Pentru dezvoltarea propriei personalităti & $28 \%$ \\
\hline & Nu ştiu/Nu răspund & $5 \%$ \\
\hline
\end{tabular}

Notă: *Întrebare cu multiple variante de răspuns. Suma procentelor nu este în mod necesar $100 \%$.

Sursa: Date obținute în urma centralizării rezultatelor pe baza chestionarului aplicat on-line la adresa https://docs.google.com/forms/u/0/ 


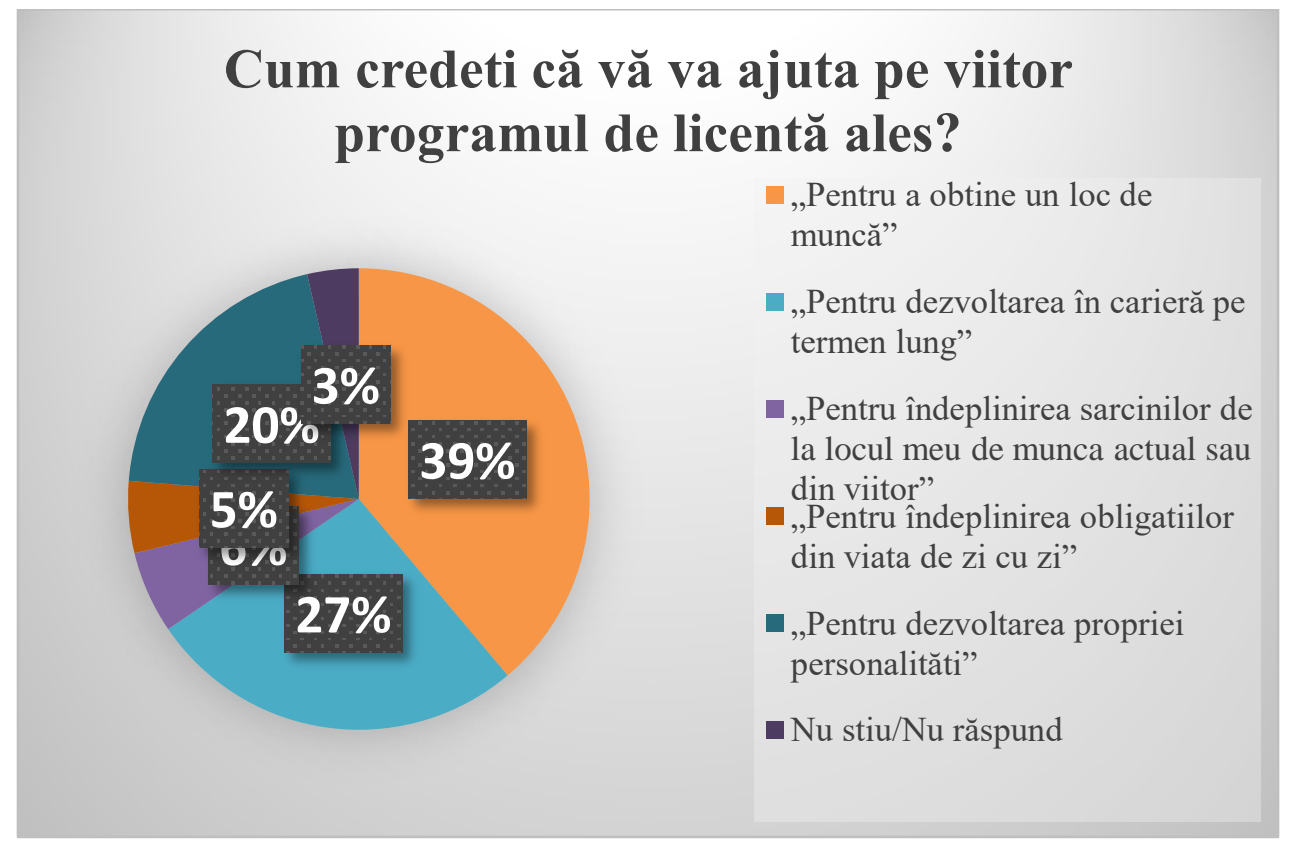

Graficul nr. 5. Utilitatea programului de licență

Sursa: Date obținute în urma centralizării rezultatelor pe baza chestionarului aplicat on-line la adresa https://docs.google.com/forms/u/0/

La această întrebare studenții au avut posobolitatea să bifeze mai multe răspunsuri, dacă au considerat necesar. Astfel, în Tabelul nr. 5 sunt distribuite date referitoare la părerea viitoriilor absolvenți despre modul în care informațiile furnizate de universitate prin cursuri îi vor ajuta la integrarea pe piaţa muncii. Majoritatea respondenților au ales, într-un procent de $39 \%$, prima variantă de răspuns, cea referitoare la obținerea unui loc de muncă după absolvire. Apoi, 27\% dintre respondenți sunt de părere că specializarea aleasă ii va ajuta pentru dezvoltarea unei cariere pe termen lung. O variantă apropiată ca procent de cea anterioară $(20 \%)$ a fost aleasă de studenții care consideră că programul de licență ii va ajuta pentru a-şi dezvolta propria personalitate. Celelalte 2 variante, referitoare la îndeplinirea sarcinilor de serviciu de la locul de muncă sau a diferitelor obligații din viața de zi cu zi, au un procentaj scăzut, de $6 \%$, respectiv 5\%. De asemenea, avem si 3 studenţi indecişi, care fie nu au ştiut în ce variantă îsi încadreze răspunsul, fie au evitat răspunsul din motive personale. 
În urma acestor rezultate constatăm că aproximativ un sfert dintre studenți se gândesc la o corelație între studii şi muncă, iar aceasta poate aduce numeroase avantaje în ceea ce priveşte angajarea.

Prin întrebarea cu numărul 6 am dorit să afăm care este stadiul activității studenților în momentul chestionării, dacă aceştia se ocupă doar de studii sau mai desfăşoară şi alte activități.

Tabelul nr. 6. Situația profesională a respondentului pe lângă cea de student

\begin{tabular}{|l|l|c|}
\hline 6. & $\begin{array}{l}\text { Care este situația Dumneavoastră actuală pe lângă cea } \\
\text { de student/ă? }\end{array}$ & $\mathbf{1 0 0} \%$ \\
\hline & Angajat & $29 \%$ \\
\hline & Participant la cursuri de formare profesională & $10 \%$ \\
\hline & Concediu pentru creşterea copilului & $1 \%$ \\
\hline & Fără loc de muncă dar în căutarea unuia & $46 \%$ \\
\hline & Fără loc de muncă şi fără intenție de angajare (boală etc.) & $4 \%$ \\
\hline & Nu ştiu / Nu răspund & $10 \%$ \\
\hline & TOTAL & $100 \%$ \\
\hline
\end{tabular}

Sursa: Date obținute în urma centralizării rezultatelor pe baza chestionarului aplicat on-line la adresa https://docs.google.com/forms/u/0/

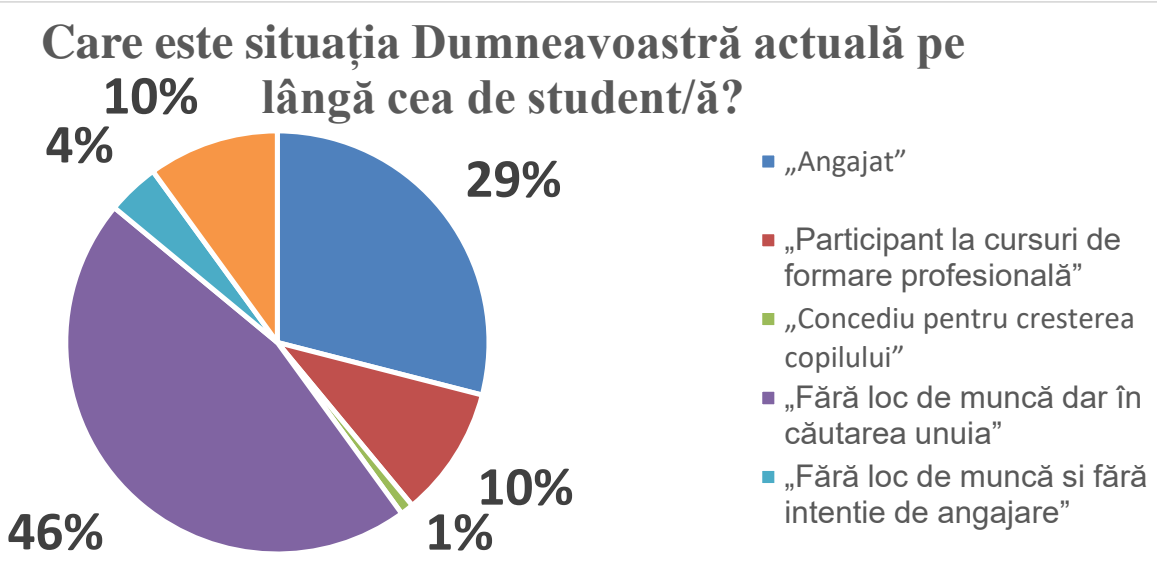

Graficul nr. 6. Situația profesională a respondentului pe lângă cea de student

Sursa: Date obținute în urma centralizării rezultatelor pe baza chestionarului aplicat on-line la adresa https://docs.google.com/forms/u/0/ 
Centralizarea răspunsurilor la această întrebare evidențiază faptul că numărul cel mai mare al persoanelor chestionate nu muncesc, însă îşi doresc să o facă. Acest lucru ar trebui să ridice un semn de întrebare referitor la cauzele care au împiedicat angajarea acestor studenți, care deşi îşi doresc să se angajeze, nu au reuşit până în momentul de faţă. Se remarcă şi categoria studenților care au reuşit să îşi împartă timpul şi energia între două activități desfăşurate concomitent. Procentul acestei categorii de studenți angajați este de doar 29\%. De asemenea, printre respondenți se află şi 10 persoane $(10 \%)$ care participă la cursuri de formare profesională, cu scopul de a-i pregăti şi ajuta pe viitor în ocuparea unui job. Tot cu acelaşi procent se identifică şi cei care din diferite motive nu au dat un răspuns concret la această întrebare. 4 din 100 de studenți nu au nicio intenție de angajare în viitorul apropiat, sens în care vom încerca să aflăm din întrebările următoare care ar putea fi posibilele motive care au condus la acest fapt, în timp ce 1\% se află în concediul de creştere a copilului.

Prin următoarea întrebare am dorit să aflăm concret numărul de studenți care nu s-au focusat doar pe programul de studii, ci au dorit să descopere şi să experimenteze activitățile şi responsabilitățile unui loc de muncă.

Tabelul nr. 7. Studenții care au fost în căutarea unui loc de muncă

\begin{tabular}{|l|l|c|}
\hline 7. & Ați fost vreodată în căutarea unui loc de muncă? & $\mathbf{1 0 0} \%$ \\
\hline & $\mathrm{Da}$ & $87 \%$ \\
\hline & $\mathrm{Nu}$ & $13 \%$ \\
\hline & TOTAL & $100 \%$ \\
\hline
\end{tabular}

Sursa: Date obținute în urma centralizării rezultatelor pe baza chestionarului aplicat on-line la adresa https://docs.google.com/forms/u/0/ 


\section{Ați fost vreodată în căutarea unui loc de muncă?}

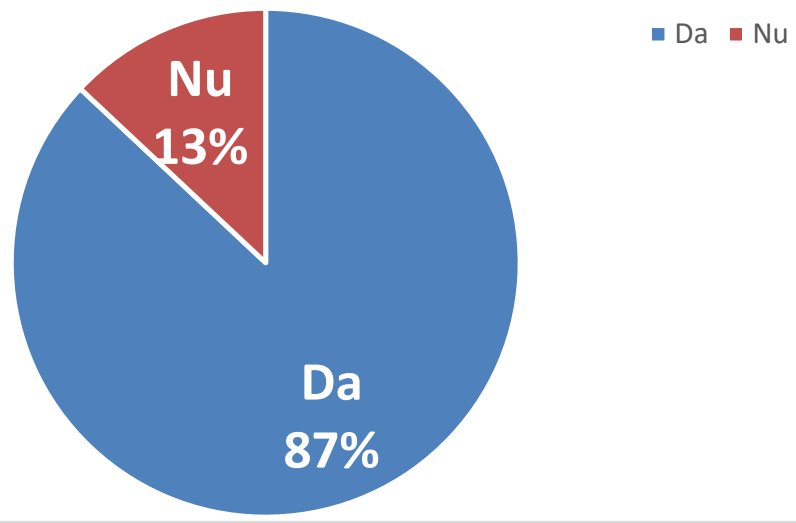

Graficul nr. 7. Studenții care au fost în căutarea unui loc de muncă

Sursa: Date obținute în urma centralizării rezultatelor pe baza chestionarului aplicat on-line la adresa https://docs.google.com/forms/u/0/

Din tabel şi grafic rezultă că $87 \%$ dintre persoanele chestionate au fost în căutarea unui loc de muncă. Acest lucru este de apreciat şi încurajat, deoarece munca încă din timpul studiilor pregăteşte studentul şi îi dă o altă viziune faţă de realitate şi, în acelaşi timp, constituie o experiență în plus cumulată la formarea sa profesională. Numărul celor care nu au fost interesați de un loc de muncă din diferite motive este redus, de doar 13\%, însă nu este de neglijat, meritând analizat mai în detaliu.

Următoarea întrebare, cu numărul 8, se referă de asemenea la interesul pe care îl manifestă studenții faţă de piaţa muncii, de aceea timpul este un factor care ne va ajuta în acest sens.

Tabelul nr. 8. Când au fost interesați studenții să muncească

\begin{tabular}{|c|l|c|}
\hline $\mathbf{8 .}$ & Când aţi încercat să vă angajaţi? & $\mathbf{1 0 0} \%$ \\
\hline & Înainte să încep cursurile liceale & $2 \%$ \\
\hline & În timpul liceului & $14 \%$ \\
\hline & Înainte de înscrierea la universitate & $20 \%$ \\
\hline & În timpul studiilor universitare & $51 \%$ \\
\hline
\end{tabular}


Integration into the Labor Market of Young Students from the "Stefan cel Mare" ... Alexandra TERLEKI

\begin{tabular}{|l|l|c|}
\hline Nu am căutat un loc de muncă & $11 \%$ \\
\hline & Nu ştiu / Nu răspund & $2 \%$ \\
\hline TOTAL & $100 \%$ \\
\hline
\end{tabular}

Sursa: Date obținute în urma centralizării rezultatelor pe baza chestionarului aplicat on-line la adresa https://docs.google.com/forms/u/0/

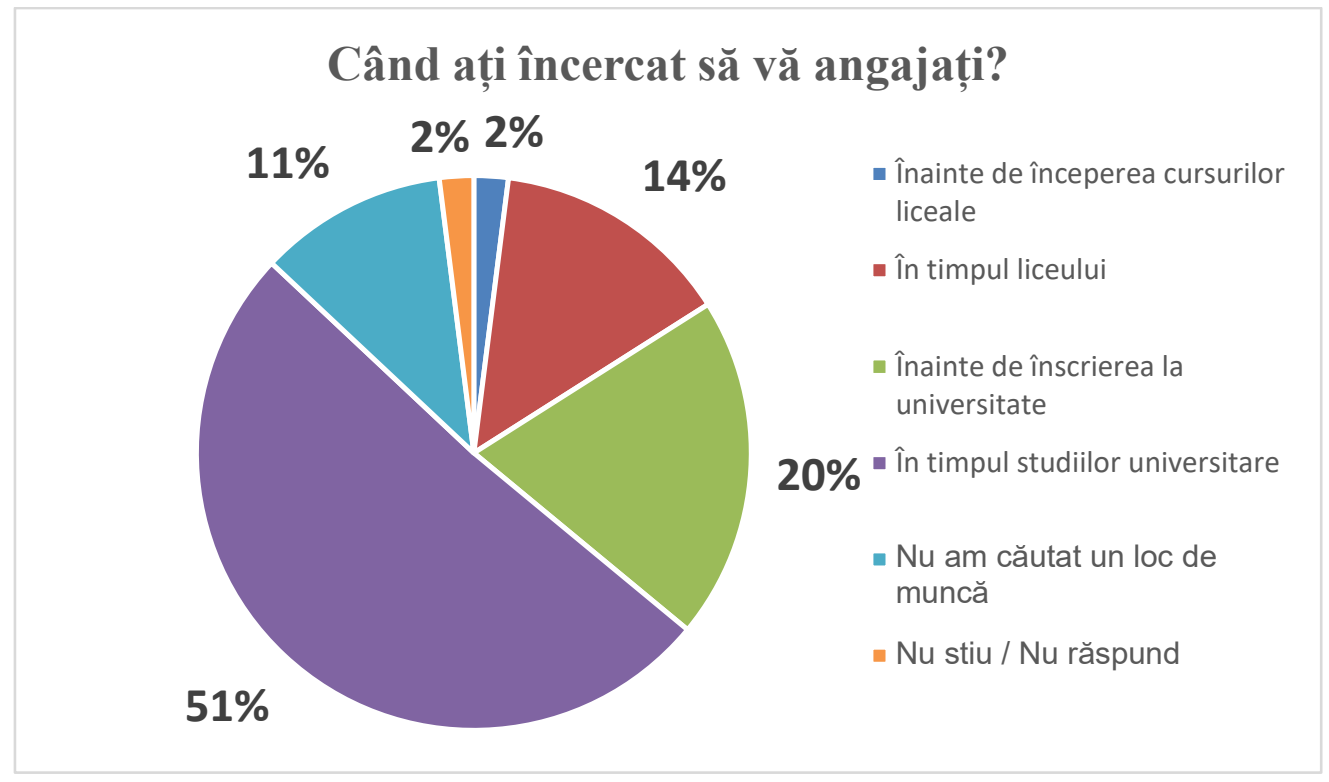

Graficul nr. 8. Când au fost interesați studenții să muncească

Sursa: Date obținute în urma centralizării rezultatelor pe baza chestionarului aplicat on-line la adresa https://docs.google.com/forms/u/0/

Având în vedere întrebarea propusă studenților, am constatat că mai mult de jumătate dintre aceştia, în proporție de $51 \%$, au început să îşi caute un loc de muncă încă din timpul studiilor universitare. Alți $20 \%$ au răspuns că au fost interesați de un loc de muncă înainte de a se înscrie la universitate, în timp ce $14 \%$ au căutat un loc de muncă în timpul liceului, iar $11 \%$ nu au fost niciodată în căutarea unui job.

Întrebările numerotate cu 9 şi 10 cuprind părerile studenților privind motivele pentru care s-ar angaja şi motivele pentru care nu s-ar angaja, pe care dorim să le analizăm în paralel, pentru a evidenția cât mai clar diferențele ponderilor între cele două categorii privind motivația sau lipsa acesteia referitor la angajare. 
Tabelul nr. 9. Motivul/motivele pentru care respondenții nu s-ar angaja

\begin{tabular}{|l|l|c|} 
9. & Care ar fi motivul/motivele pentru care v-aţi angaja? * & \\
\hline & Din curiozitate & $12 \%$ \\
\hline & Din placerea de a munci & $27 \%$ \\
\hline & Din diferite necesități financiare & $76 \%$ \\
\hline & Pentru experiență la CV & $31 \%$ \\
\hline & $\mathrm{Nu}$ aş avea motive & $1 \%$ \\
\hline & $\mathrm{Nu}$ ştiu / Nu răspund & $1 \%$ \\
\hline
\end{tabular}

Notă: *întrebare cu multiple variante de răspuns. Suma procentelor nu este în mod necesar $100 \%$.

Sursa: Date obținute în urma centralizării rezultatelor pe baza chestionarului aplicat on-line la adresa https://docs.google.com/forms/u/0/

În ceea ce priveşte părerile pro angajare a celor care sunt motivați în obțierea unui loc de muncă, conform datelor centralizate în tabelul nr. 9, cele mai multe răspunsuri s-au înregistrat în dreptul variantei de răspuns referitoare la necesitățile financiare, cu un procent majoritar de 76\%. In urma acestui rezultat putem interpreta că majoritatea studenților respondenți doresc să fie independenți financiar, fără a depinde de cei din jur, ceea ce este de apreciat şi susţinut. Pe lângă acest motiv principal, respondenţii s-au referit şi la varianta referitoare la CV, această motivație acumulând un procent de $31 \%$. Având în vedere că tot mai mulți angajatori doresc de la candidații pentru post experiență în domeniu, tinerii încearcă încă din timpul facultăţii să înceapă cat mai devreme să îşi îmbogățească CV-ul - şi nu numai - cu experiența dobândită la un loc de muncă. Cu o pondere de $27 \%$ se remarcă tinerii care nu se gândesc la obținearea unei recompense atunci cand îşi caută un loc de muncă, ci doresc să îşi rezolve atribuțiile zilnice din plăcere.

Având în vedere că mulți dintre studenți nu au avut ocazia să experimenteze provocările aduse de un loc de muncă, îşi doresc obținerea unuia din simplă curiozitate, această variantă fiind valabilă pentru un număr de 12 studenți. $\mathrm{Cu}$ un procent de $1 \%$ s-au înregistrat şi penultimele două variantele, cele în care respondentul nu ar avea un motiv întemeiat să muncească sau nu este hotărât asupra variantei care ar cântări mai mult în decizia angajării. 
Integration into the Labor Market of Young Students from the "Stefan cel Mare" ... Alexandra TERLEKI

Tabelul nr. 10. Motivul/motivele pentru care respondenții nu s-ar angaja

\begin{tabular}{|l|l|c|}
\hline 10. & $\begin{array}{l}\text { Din ce motiv/motive nu v-ați angajat până în prezent/ nu } \\
\text { doriți să vă angajați pe viitor? } *\end{array}$ & \\
\hline & Sunt susţinut/ă financiar de către părinți/rude/prieteni & $16 \%$ \\
\hline Nu am găsit postul potrivit & $27 \%$ \\
\hline & Programul cursurilor nu îmi permite & $49 \%$ \\
\hline & Nu mă simt pregătit/pregătită & $7 \%$ \\
\hline & Desfăşor alte activităţi & $17 \%$ \\
\hline & Nu doresc/ Nu am motiv & $7 \%$ \\
\hline & Altă variantă & $12 \%$ \\
\hline
\end{tabular}

Notă: *întrebare cu multiple variante de răspuns. Suma procentelor nu este în mod necesar $100 \%$.

Sursa: Date obținute în urma centralizării rezultatelor pe baza chestionarului aplicat on-line la adresa https://docs.google.com/forms/u/0/

Mulți dintre studenții care muncesc sau care şi-ar dori să muncească spun că programul cursurilor nu îi avantajează în susținerea acestei activități (49\%). În ordine descrescătoare, următorul motiv, indicat de un număr de 27 de respondenți, se referă la nepotrivirea postului, a responsabilităților din cadrul acestuia cu pergătirea sau cunoştințele la care s-a aşteptat studentul. La o diferență de un procent se află motivul care constă în aceea că persoana nu s-a angajat deoarece desfăşoară alte activități $(17 \%)$ şi probabil timpul nu îi permite sau pur şi simplu nu are vreun motiv solid care să cântărească în favoarea angajării $(16 \%)$. De asemenea, studenții au avut la final şi o variantă de răspuns deschisă (pentru care au optat în procent de $12 \%$ ), prin care şi-au putut exprima propriile motive, majoritatea referindu-se la cele existente deja. Procentul cel mai scăzut, de 7\%, se încadrează atât în dreptul studenților care nu cred că au abilităţile necesare pentru a îndeplini responsabilităţile unui loc de muncă, cât şi în dreptul răspunsului „Nu ştiu/Nu răspund”. 

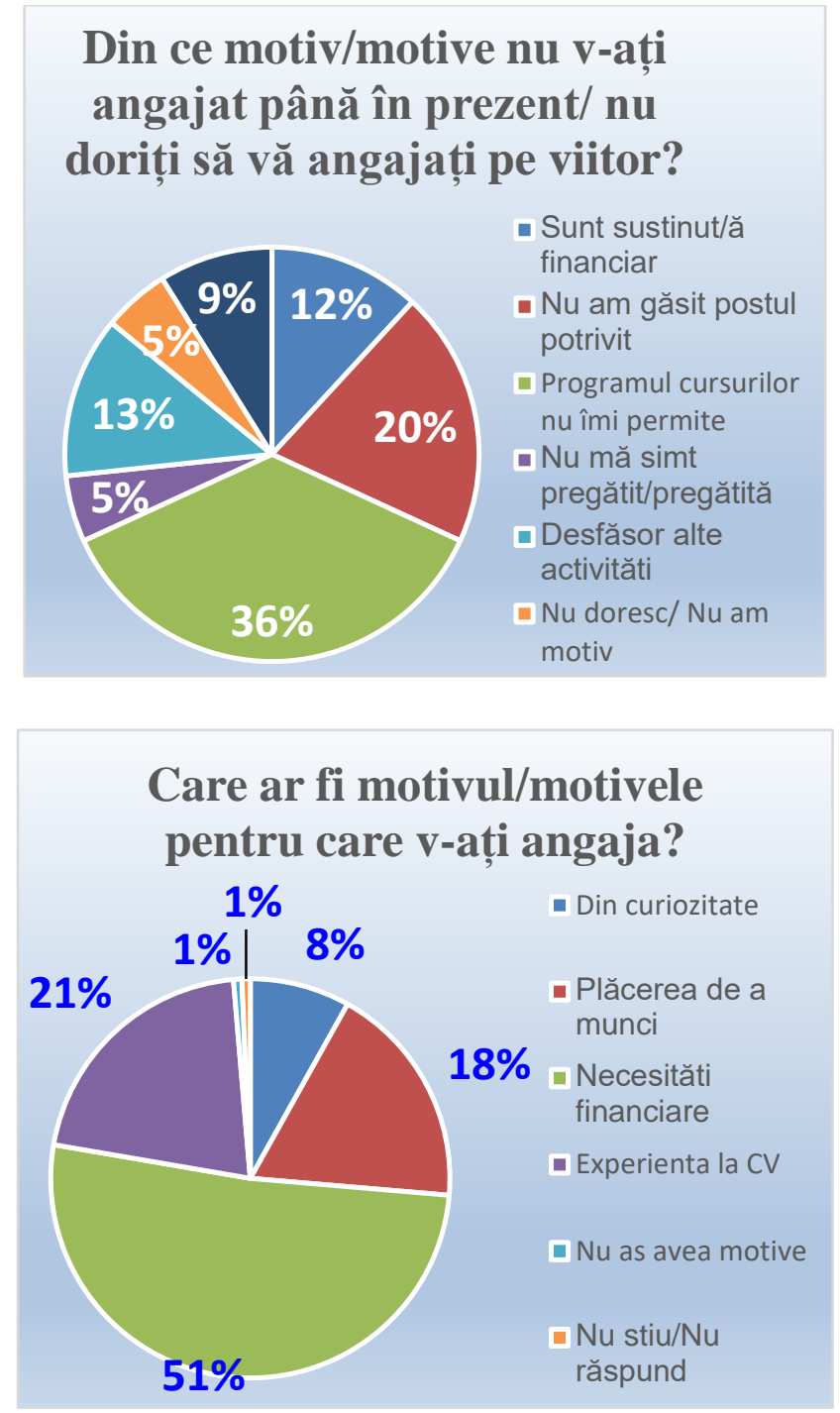

Graficul nr. 9. Motivul/motivele pentru care respondenții nu s-au angajat/nu s-ar angaja

Sursa: Date obținute în urma centralizării rezultatelor pe baza chestionarului aplicat on-line la adresa https://docs.google.com/forms/u/0/

Analizând cele două grafice, putem observa că numărul celor care sunt dispuşi să se angajeze datorită necesităţilor financiare au ca şi impediment programul cursurilor, care nu le permite şi prestarea orelor de la locul de muncă. De exemplu, un student care doreşte să obțină rezultate cât mai bune 
Integration into the Labor Market of Young Students from the "Stefan cel Mare" ... Alexandra TERLEKI

pentru a se încadra la forma de buget sau pentru a obține o bursă de merit (şi nu poate lipsi de la cursurile distribuite în orar pe întreaga zi), nu va reuşi să respecte şi programul de muncă de 8 ore la care se obligă la un eventual angajator.

Un alt exemplu, potrivit graficului, se referă la faptul că studenții care îşi doresc să muncească pentru a putea aduna experiență pe care să o adauge la $\mathrm{CV}$ nu au fost mulțumiți de posturile pentru care au aplicat, considerându-le nepotrivite pentru nivelul lor de pregătie sau pentru aşteptările pe care le-au avut iniţial.

Prin intermediul întrebării numărului 11 am dorit să aflăm care sunt cele mai folosite metode prin care studenţii încearcă să îşi găsească un loc de muncă.

Tabelul nr. 11. Metode de căutare a unui loc de muncă

\begin{tabular}{|c|c|c|}
\hline 11. & Cum încercaţi de obicei să vă căutați un loc de muncă? & $100 \%$ \\
\hline & Am depus cerere de angajare pentru un loc de muncă vacant. & $18 \%$ \\
\hline & $\begin{array}{l}\text { Am contractat angajatorii din proprie inițiativă fără a şti de } \\
\text { existența unui loc de muncă disponibil. }\end{array}$ & $6 \%$ \\
\hline & Am fost contactat de un angajator. & $9 \%$ \\
\hline & $\mathrm{Cu}$ ajutorul familiei, prietenilor sau cunoștințelor. & $29 \%$ \\
\hline & Prin intermediul rețelelor sociale & $13 \%$ \\
\hline & $\begin{array}{l}\text { Prin intermediul grupurilor de discuții şi al listelor de e-mail } \\
\text { de pe internet }\end{array}$ & $3 \%$ \\
\hline & $\mathrm{Cu}$ ajutorul presei scrise & $1 \%$ \\
\hline & $\mathrm{Cu}$ ajutorul portalurilor de locuri de muncă & $15 \%$ \\
\hline & Lucrez pentru propria afacere de familie & - \\
\hline & Mi-am deschis propria afacere & - \\
\hline & Altfel (M-am înscris la concurs pentru postul vacant etc.) & $6 \%$ \\
\hline & TOTAL & $100 \%$ \\
\hline
\end{tabular}

Sursa: Date obținute în urma centralizării rezultatelor pe baza chestionarului aplicat on-line la adresa https://docs.google.com/forms/u/0/ 


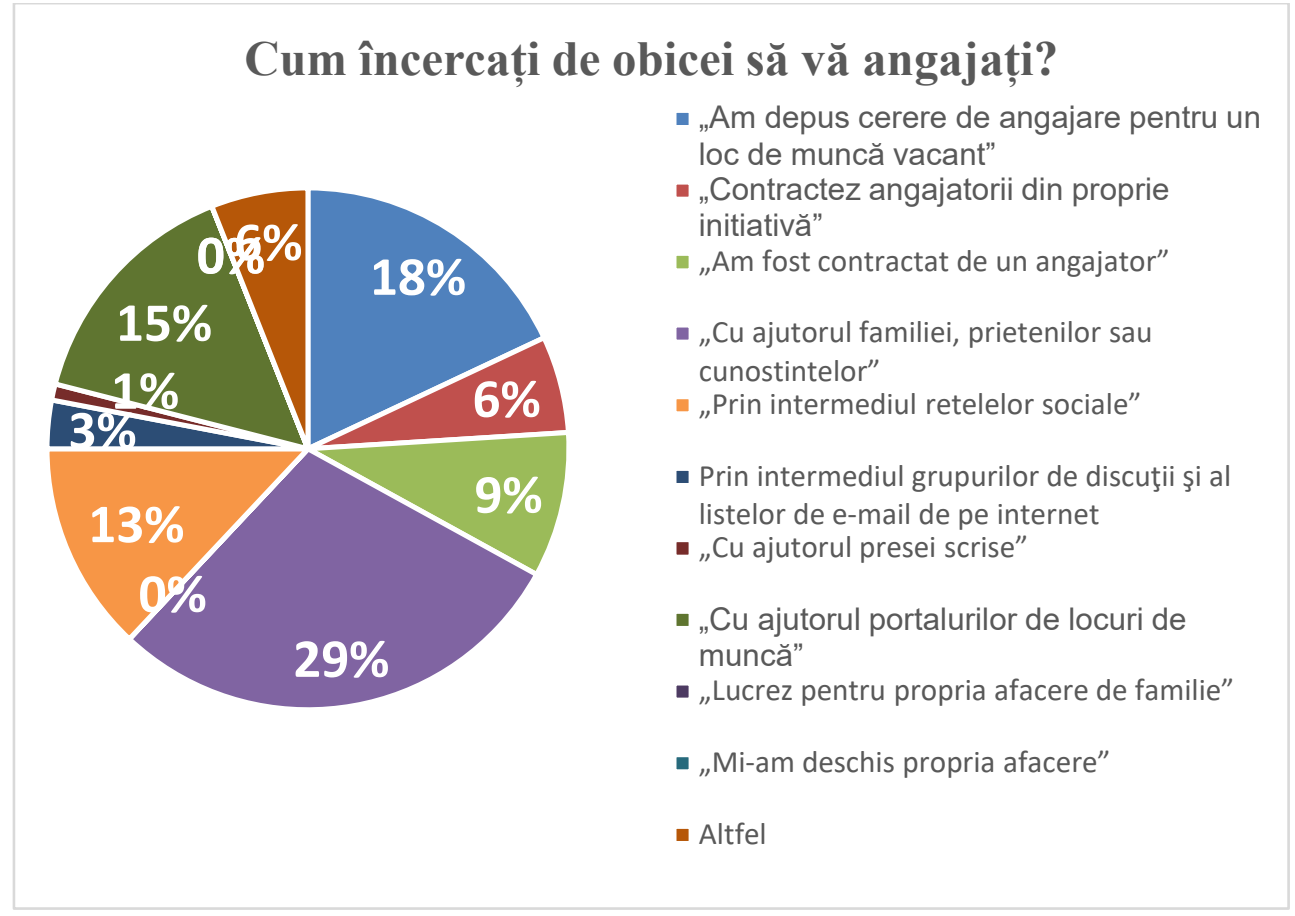

Graficul nr. 10. Metode de căutare a unui loc de muncă

Sursa: Date obținute în urma centralizării rezultatelor pe baza chestionarului aplicat on-line la adresa https://docs.google.com/forms/u/0/

Din totalul celor 100 de studenți participanți la cercetare, 29 şi-au găsit locul de muncă prin intermediul familiei, prietenilor sau cunoştințelor, iar alți 18 studenţi şi-au găsit locul de muncă actual prin „depunerea unei cereri de angajare pentru postul de muncă”, pe care îl ştiau a fi vacant. Metoda referitoare la căutarea unui loc de muncă prin intermediul portalurilor de locuri de muncă este preferată de un număr de 15 respondenți, neexistând o mare diferență între aceasta şi cea a rețelelor de socializare (13\%).

Conform rezultatelor cercetării, acestea sunt cele mai de frecvente metode prin care studenții găsesc un loc de muncă. La mare distanță se află grupurile de discuții sau email-ul (3\%), presa scrisă $(1 \%)$ sau deschiderea propriei afaceri ori implicarea într-o afacere de familie $(0 \%)$.

Pin următoarea întrebare am dorit să aflăm cât de interesaţi şi predispuşi sunt studenții de a li se acorda ajutor şi de a fi orientați în alegerea unui loc de muncă potrivit. 
Integration into the Labor Market of Young Students from the "Stefan cel Mare" ... Alexandra TERLEKI

Tabelul nr. 12. Rolul „Centrului de Consiliere şi Orientare în Carieră din USV” pentru ghidarea studenților

\begin{tabular}{|l|l|c|}
\hline 12. & $\begin{array}{l}\text { Credeți că are un rol important "Centrul de Consiliere şi } \\
\text { Orientare în Carieră din USV” pentru ghidarea } \\
\text { studenților? }\end{array}$ & $\mathbf{1 0 0} \%$ \\
\hline $\mathrm{Da}$ & $68 \%$ \\
\hline $\mathrm{Nu}$ & $27 \%$ \\
\hline $\mathrm{Nu}$ ştiu/ Nu răspund & $5 \%$ \\
\hline TOTAL & $100 \%$ \\
\hline
\end{tabular}

Sursa: Date obținute în urma centralizării rezultatelor pe baza chestionarului aplicat on-line la adresa https://docs.google.com/forms/u/0/

\section{Credeți că are un rol important „Centrul de Consiliere și Orientare în Carieră din USV" pentru ghidarea studenților?}

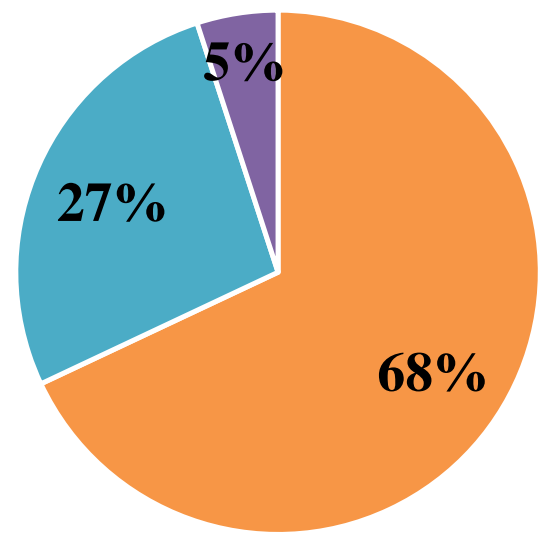

- Da

- Nu

- Nu stiu/Nu răspund

Graficul nr. 11. Rolul „Centrului de Consiliere şi Orientare în Carieră din USV” pentru ghidarea studenților

Sursa: Date obținute în urma centralizării rezultatelor pe baza chestionarului aplicat on-line la adresa https://docs.google.com/forms/u/0/

Potrivit datelor din tabel, un procent major de 68\% din totalul nostru de studenți au răspuns că rolul acestui centru este important, însă un procent de $27 \%$ dintre studenți nu sunt de aceeaşi părere. Numărul celor care au ales în proporție de 5\% ultima variantă se datorează, presupunem, faptului că nu 
cunosc informații în legătură cu acest centru, nu au apelat şi nu au participat la diferitele training-uri sau evenimente oferite pentru studenți.

Prin intermediul acestei întrebări am încercat să conturăm o imagine despre legătura pe care o creează studenții între universitate şi locul de muncă.

Tabelul nr. 13. Criteriile angajatorului în oferirea unui loc de muncă

\begin{tabular}{|l|l|c|}
\hline 13. & $\begin{array}{l}\text { Care din următoarele aspecte credeți că vă va ajuta să } \\
\text { vă angajați pe viitor? }\end{array}$ & $\mathbf{1 0 0} \mathbf{\%}$ \\
\hline & Specializarea/ Programul de studii & $18 \%$ \\
\hline & Reputația universității, facultății & $11 \%$ \\
\hline & Personalitatea mea & $24 \%$ \\
\hline & Potențialul meu de a munci & $30 \%$ \\
\hline & Recomandările foştilor angajatori sau ale cunoştințelor & $17 \%$ \\
\hline & TOTAL & $100 \%$ \\
\hline
\end{tabular}

Sursa: Date obținute în urma centralizării rezultatelor pe baza chestionarului aplicat on-line la adresa https://docs.google.com/forms/u/0/

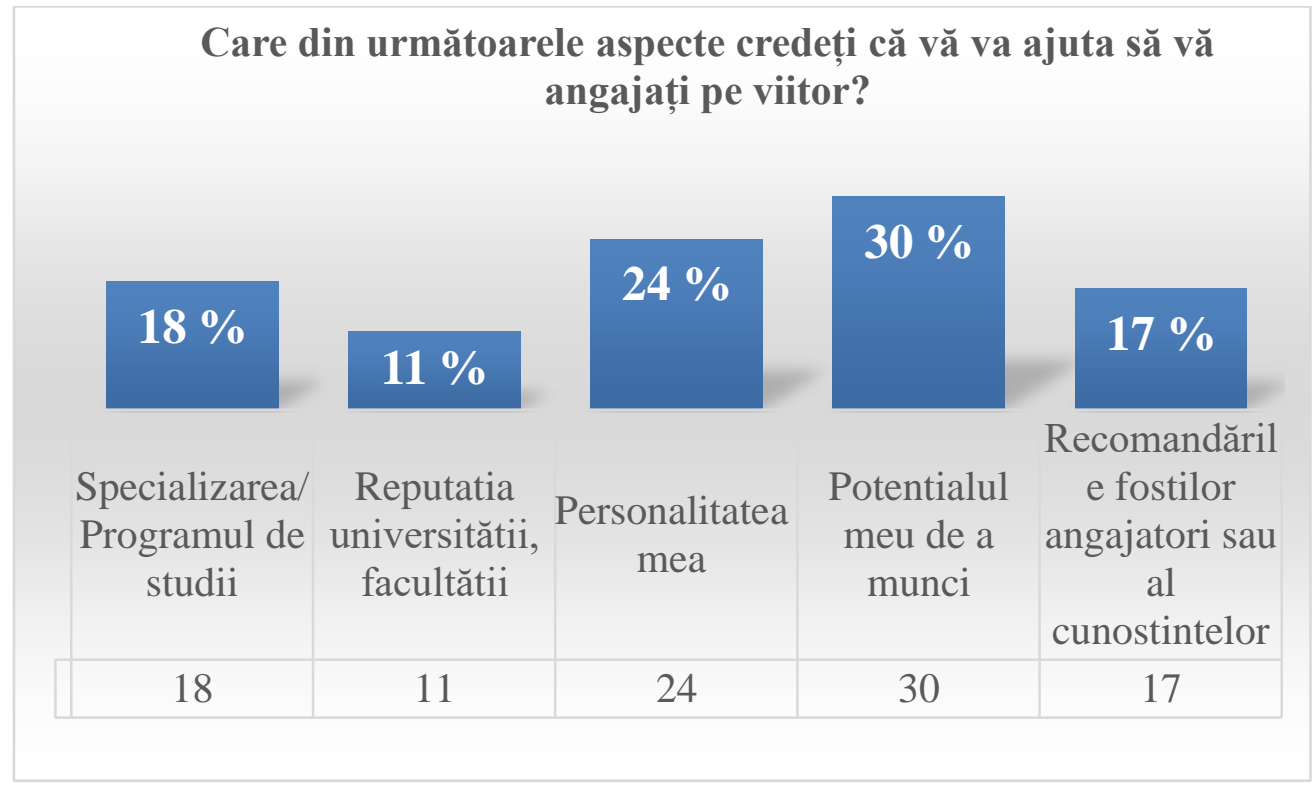

Graficul nr. 12. Criteriile angajatorului în oferirea unui loc de muncă

Sursa: Date obținute în urma centralizării rezultatelor pe baza chestionarului aplicat on-line la adresa https://docs.google.com/forms/u/0/ 
Într-un procent de $18 \%$, studenții sunt de părere că angajatorul urmăreşte programul de studii, $11 \%$ spun că reputația universității l-ar ajuta să se angajeze pe viitor. Alți 24 de studenți au incredere în forțele proprii şi spun că personalitatea este factorul decizional pentru angajator, 30\% sunt de părere că propria capacitate de relaționare al fiecăruia face diferența, pe când 17 spun că recomandările altor persoane î vor convinge pe angajatori în recrutarea personalului.

Intrebarea numărul 14 se referă la gradul de corespondență între domeniul studiilor şi domeniul în care muncesc studenții.

Tabelul nr. 14. Corespondența între specializarea studiată şi domeniul în muncă

\begin{tabular}{|l|l|c|}
\hline 14. & $\begin{array}{l}\text { Domeniul în care sunteți/ați dorit sa vă angajați } \\
\text { corespunde cu domeniul la care studiați? }\end{array}$ & $\mathbf{1 0 0} \%$ \\
\hline & $\mathrm{Da}$, în mare parte & $39 \%$ \\
\hline $\mathrm{Nu}$ & $61 \%$ \\
\hline TOTAL & $100 \%$ \\
\hline
\end{tabular}

Sursa: Date obținute în urma centralizării rezultatelor pe baza chestionarului aplicat on-line la adresa https://docs.google.com/forms/u/0/

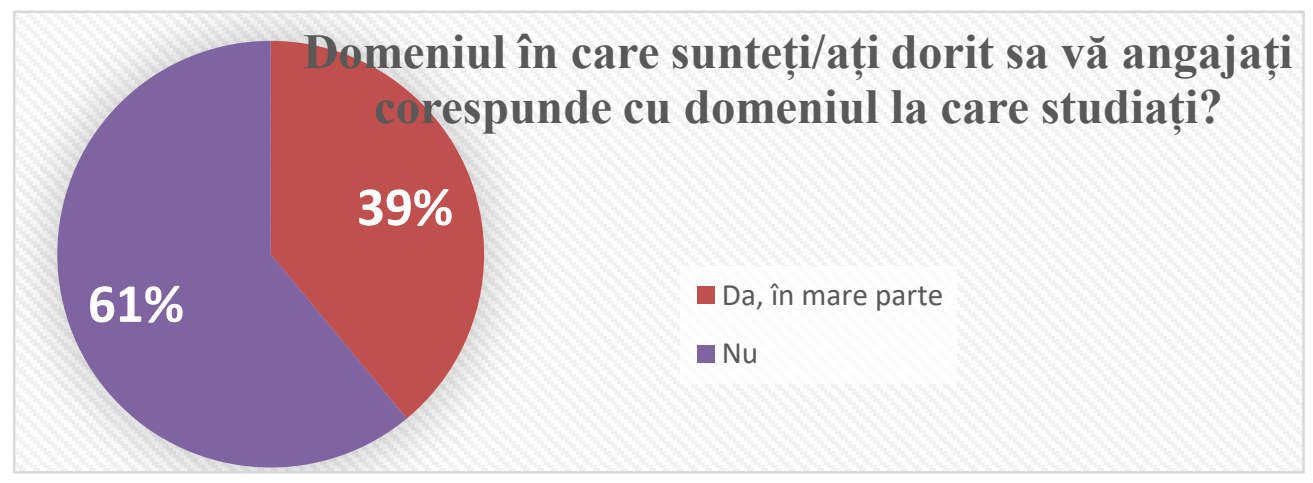

Graficul nr. 13. Corespondența între specializarea studiată şi domeniul în muncă

Sursa: Date obținute în urma centralizării rezultatelor pe baza chestionarului aplicat on-line la adresa https://docs.google.com/forms/u/0/

Prin intermediul acestei întrebări ne putem da seama în ce măsură reuşesc studenții să se angajeze în domeniul în care au studiat. Prin urmare, $61 \%$ au răspuns că domeniul în care s-au angajat sau ar dori să se angajeze nu corespunde cu domeniul în care s-au pregătit, însă există şi situații în care aceştia au reusit, într-un procent de 39\%. 
Întrebarea numărul 15 se referă la „piedicile” care pot cauza nereuşite la angajare.

Tabelul nr. 15. Din ce cauză întâmpină studenții obstacole la angajare

\begin{tabular}{|l|l|c|}
\hline 15. & $\begin{array}{l}\text { Care credeți că ar fi motivul principal în cauza căruia } \\
\text { studenții întâmpină „obstacole” la angajare? }\end{array}$ & $\mathbf{1 0 0} \%$ \\
\hline & Vârsta & $4 \%$ \\
\hline & Dificultăți de integrare într-un colectiv & $3 \%$ \\
\hline & Lipsa experienței profesionale & $79 \%$ \\
\hline & Lipsa motivației & $9 \%$ \\
\hline & Altă variantă & $5 \%$ \\
\hline & TOTAL & $100 \%$ \\
\hline
\end{tabular}

Sursa: Date obținute în urma centralizării rezultatelor pe baza chestionarului aplicat on-line la adresa https://docs.google.com/forms/u/0/

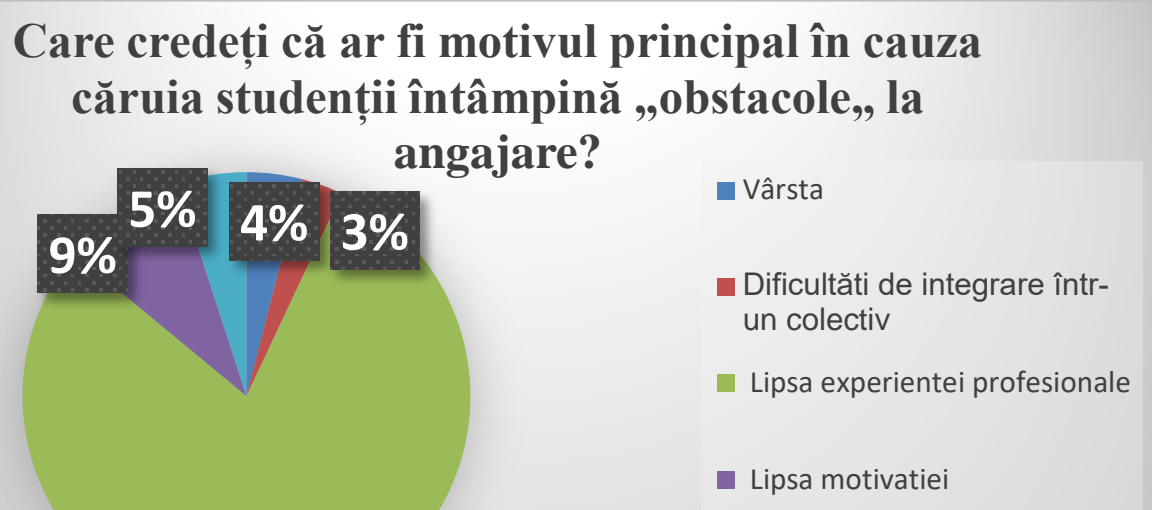

$79 \%$

Graficul nr. 14. Din ce cauză întâmpină studenții obstacole la angajare

Sursa: Date obținute în urma centralizării rezultatelor pe baza chestionarului aplicat on-line la adresa https://docs.google.com/forms/u/0/

În momentul în care sunt întrebaţi despre obstacolele pe care le întâlnesc la angajare, foarte mulți dintre studenți, în cazul nostru $79 \%$, au declarat că sunt nemulțumiţi de cerinţele managerilor în privinţa experienței în domeniu, care pentru foarte mulţi tineri aflați la începutul carierei profesionale este dificil de obținut. După părerea studenților, aceasta este cea mai importantă cauză care îi împiedică să aplice pentru postul dorit, însă mai sunt şi 
Integration into the Labor Market of Young Students from the "Stefan cel Mare" ... Alexandra TERLEKI

altele obstacole, cu procent mai scăzut, cum ar fi vârsta (4\%), integrarea cu dificiltăți într-un colectiv (3\%) sau lipsa motivației, înregistrată cu 9\%. La această întrebare studenții au ales şi o altă variantă de răspuns, într-un procent de $5 \%$, dintre care enumerăm: pregătirea slabă în domeniu, lipsa cunoştinţelor practice sau lipsa timpului, datorită orarului de studiu.

Întrebarea numărul 16 se referă la măsura în care cred studenții că lipsa experienței poate constitui un dezavantaj în ocuparea postului de muncă dorit.

Tabelul nr. 16. Măsura în care poate constitui un dezavantaj lipsa experienței profesionale

\begin{tabular}{|l|l|c|}
\hline 16. & $\begin{array}{l}\text { În ce măsură considerați că lipsa experienței } \\
\text { profesionale poate fi un dezavantaj în ocuparea postului } \\
\text { de muncă dorit? }\end{array}$ & $\mathbf{1 0 0} \%$ \\
\hline & În foarte mică măsură & $4 \%$ \\
\hline & În mică măsură & $5 \%$ \\
\hline & Nici în mică, nici în mare măsură & $25 \%$ \\
\hline & În mare măsură & $26 \%$ \\
\hline & In foarte mare măsură & $40 \%$ \\
\hline & TOTAL & $100 \%$ \\
\hline
\end{tabular}

Sursa: Date obținute în urma centralizării rezultatelor pe baza chestionarului aplicat on-line la adresa https://docs.google.com/forms/u/0/

\section{În ce măsură considerați că lipsa experienței profesionale poate fi un dezavantaj pentru ocuparea postului de muncă dorit?}

„În foarte mare măsură" „În mare măsură"

„Nici în mică nici în mare măsură" „În mică măsură” „În foarte mică măsură”

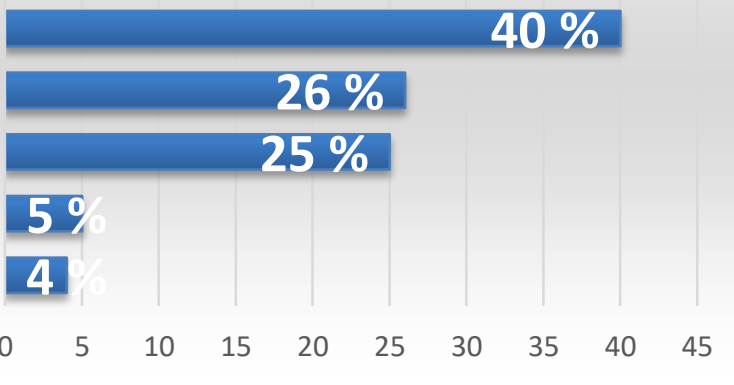

Graficul nr. 15. Măsura în care poate constitui un dezavantaj lipsa experienței profesionale

Sursa: Date obținute în urma centralizării rezultatelor pe baza chestionarului aplicat on-line la adresa https://docs.google.com/forms/u/0/ 
Având în vedere că la întrebarea anterioară majoritatea studenţilor au fost de părere că lipsa experienței profesionale este un impediment pentru carieră, şi de această dată se poate observa în grafic că această problemă este considerată un dezavantaj, însă într-un procent mai mic faţă de cel de la întrebarea anterioară, de doar $40 \%$. Există şi persoane care susțin că această condiție este valabilă într-o mare măsură, dar nu decisivă (25-26\%), dar şi câteva persoane care nu sunt de acord că experiența profesională este un criteriu determinant la angajare (4-5\%).

Având în vedere cele două întrebări (15 şi 16), putem spune că studenții care au lucrat în timpul studiilor vor avea mai multe şanse în găsirea unui job potrivit după finalizarea studiilor decât cei care nu au avut un contract de muncă. Prin urmare, participarea timpurie a studenților pe piaţa muncii reprezintă un avantaj în uşurința găsirii jobului convenabil după finalizarea studiilor universitare.

Întrebarea 17 se referă la gradul de satisfacție al studenților față de situația profesională actuală.

Tabelul nr. 17. Mulțumirea studenților față de situația lor profesională

\begin{tabular}{|l|l|c|}
\hline 17. & $\begin{array}{l}\text { Sunteți mulțumit/ă de situația Dumneavoastră } \\
\text { profesională actuală? }\end{array}$ & $\mathbf{1 0 0} \%$ \\
\hline & $\mathrm{Da}$ & $48 \%$ \\
\hline & $\mathrm{Nu}$ & $52 \%$ \\
\hline & TOTAL & $100 \%$ \\
\hline
\end{tabular}

Sursa: Date obținute în urma centralizării rezultatelor pe baza chestionarului aplicat on-line la adresa https://docs.google.com/forms/u/0/

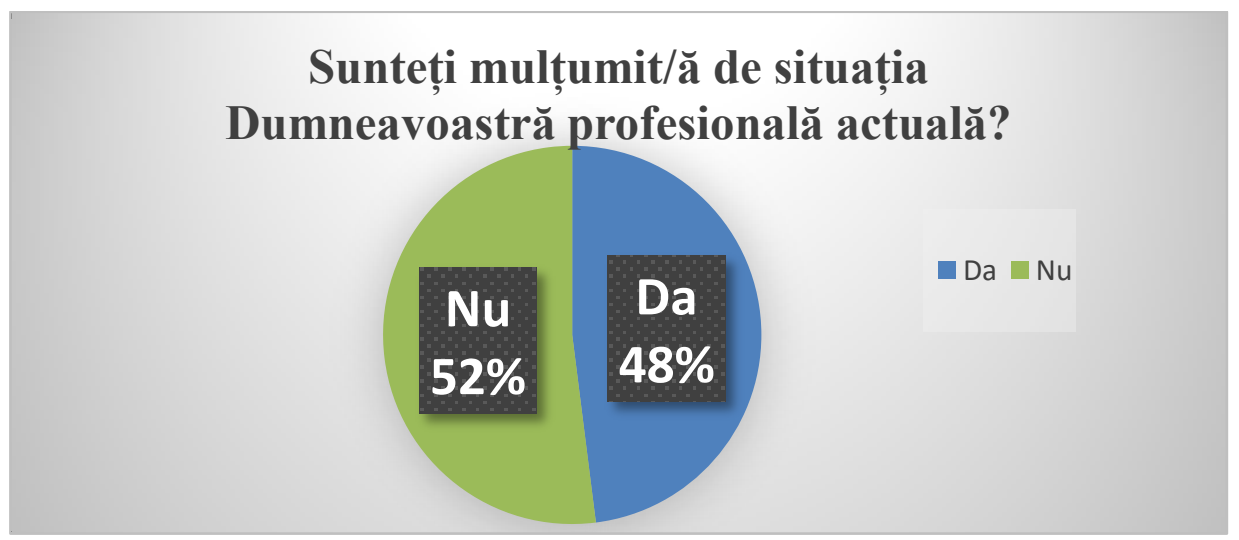

Graficul nr. 16. Mulțumirea studenților față de situația lor profesională

Sursa: Date obținute în urma centralizării rezultatelor pe baza chestionarului aplicat on-line la adresa https://docs.google.com/forms/u/0/ 
Integration into the Labor Market of Young Students from the "Stefan cel Mare" ... Alexandra TERLEKI

La această întrebare valorile sunt strâns legate unele de celelalte, sumele fiind foarte apropiate, însă se poate face o deosebire între cele două. Prin urmare, conform graficului de mai sus, putem constata că numărul celor care sunt nemulțumiți de situația lor profesională este mai ridicat $(52 \%)$, iar cei care se declară mulțumiți sunt într-un număr minoritar, de 48\%.

Întrebarea cu numărul 18 se referă la implicarea statului în a ajuta tinerii care termină un anumit ciclu de învăţămînt şi sunt în căutarea unui loc de muncă.

Tabelul nr. 18. Repartizarea locurilor de muncă de către stat pentru cei cu studiile finalizate

\begin{tabular}{|l|l|c|}
\hline 18. & $\begin{array}{l}\text { Credeți că este potrivit ca statul să ne asigure un loc de } \\
\text { muncă la finalizarea unor studii? }\end{array}$ & $\mathbf{1 0 0} \%$ \\
\hline & $\mathrm{Da}$ & $81 \%$ \\
\hline & $\mathrm{Nu}$ & $10 \%$ \\
\hline & $\mathrm{Nu}$ ştiu / Nu răspund & $9 \%$ \\
\hline & TOTAL & $100 \%$ \\
\hline
\end{tabular}

Sursa: Date obținute în urma centralizării rezultatelor pe baza chestionarului aplicat on-line la adresa https://docs.google.com/forms/u/0/

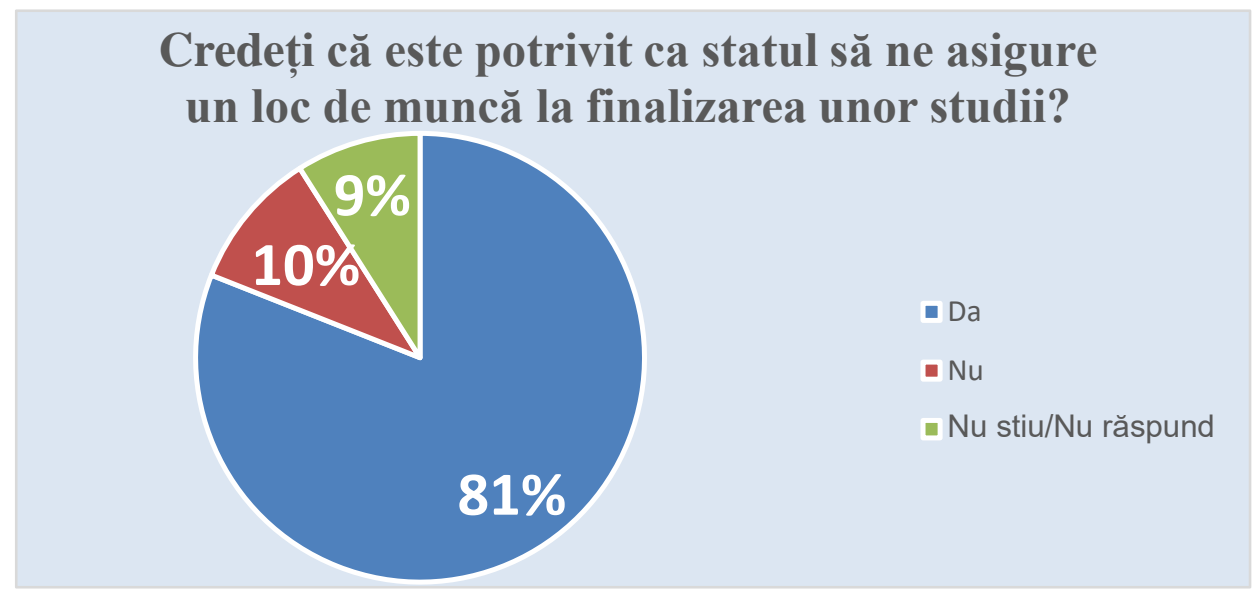

Graficul nr. 17. Repartizarea locurilor de muncă de către stat pentru cei cu studiile finalizate

Sursa: Date obținute în urma centralizării rezultatelor pe baza chestionarului aplicat on-line la adresa https://docs.google.com/forms/u/0/ 
Ceea ce este surprinzător este faptul că mulți dintre tinerii chestionați sunt de acord ca statul să le repartizeze un loc de muncă după finalizarea studiilor, aşa cum se întâmpla masiv în perioada anterioară anului 1989. Prin urmare, observăm că $81 \%$ au fost de acord cu această propunere, $9 \%$ au fost imparțiali, în timp ce 10\% au respins această idee. Considerăm că studenții au răspuns pozitiv acestei întrebări deoarece este tot mai dificilă găsirea unui loc de muncă, în domeniul în care au studiat.

Întrebarea nr. 19 se referă la capacitatea numărului de locuri de muncă al județului Suceava.

Tabelul nr. 19. Suficiența/insuficiența locurilor de muncă din județul Suceava

\begin{tabular}{|l|l|c|}
\hline 19. & $\begin{array}{l}\text { În momentul de față, considerați că piața forței de muncă } \\
\text { din județului Suceava este pregătită cu sufieciente posturi } \\
\text { vacante pentru noii absolvenți ai promoției } 2018 \text { dornici de } \\
\text { a munci? }\end{array}$ & $\mathbf{1 0 0 ~ \%}$ \\
\hline $\mathrm{Da}$ & $4 \%$ \\
\hline $\mathrm{Nu}$ & $81 \%$ \\
\hline $\mathrm{Nu}$ ştiu / Nu răspund & $15 \%$ \\
\hline TOTAL & $100 \%$ \\
\hline
\end{tabular}

Sursa: Date obținute în urma centralizării rezultatelor pe baza chestionarului aplicat on-line la adresa https://docs.google.com/forms/u/0/

\section{Piața muncii din județului Suceava este pregătită} cu sufieciente posturi vacante pentru noii absolvenți ai promoției 2018 dornici de a munci?

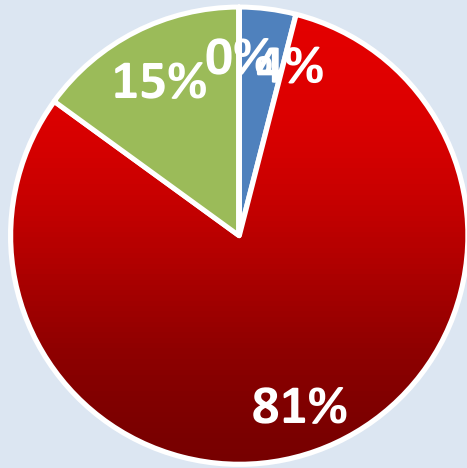

- Da

- $\mathrm{Nu}$

- Nu stiu/Nu răspund

Graficul nr. 18. Suficiența/insuficiența locurilor de muncă din județul Suceava

Sursa: Date obținute în urma centralizării rezultatelor pe baza chestionarului aplicat on-line la adresa https://docs.google.com/forms/u/0/ 
Integration into the Labor Market of Young Students from the "Stefan cel Mare" ... Alexandra TERLEKI

Observând graficul, cei mai mulți dintre studenţi au răspuns negative, în proporție de $81 \%$, cei care nu au putut oferi o opinie la această întrebare au avut o pondere de $15 \%$, iar cei care susțin că fiecare student are asigurat un loc de muncă în județul Suceava au înregistrat un procent de 4\%.

Din această întrebare putem vedea clar nemulţumirea studenţilor faţă de numărul locurilor disponibile pe piața muncii sucevene.

Am considerat necesară inițierea întrebării cu numărul 20 pentru a afla care este următorul pas pe care îl vor face studenții după finalizarea studiilor de licenţă.

Tabelul nr. 20. Parcursul în carieră după absolvirea ciclului de licență

\begin{tabular}{|l|l|c|}
\hline 20. & $\begin{array}{l}\text { Care este următorul pas pe care îl faceți după absolvirea } \\
\text { studiilor de licență? * }\end{array}$ & \\
\hline & Voi urma un program de master & $44 \%$ \\
\hline & Voi ramâne la jobul actual & $9 \%$ \\
\hline & Voi căuta un loc de muncă & $57 \%$ \\
\hline & Voi aplica pentru şomaj & - \\
\hline & Nu sunt hotărât/ă & $15 \%$ \\
\hline & Altă variantă (plec în străinătate, afacere personală) & $5 \%$ \\
\hline
\end{tabular}

Notă: *Întrebare cu multiple variante de răspuns. Suma procentelor nu este în mod necesar $100 \%$.

Sursa: Date obținute în urma centralizării rezultatelor pe baza chestionarului aplicat on-line la adresa https://docs.google.com/forms/u/0/

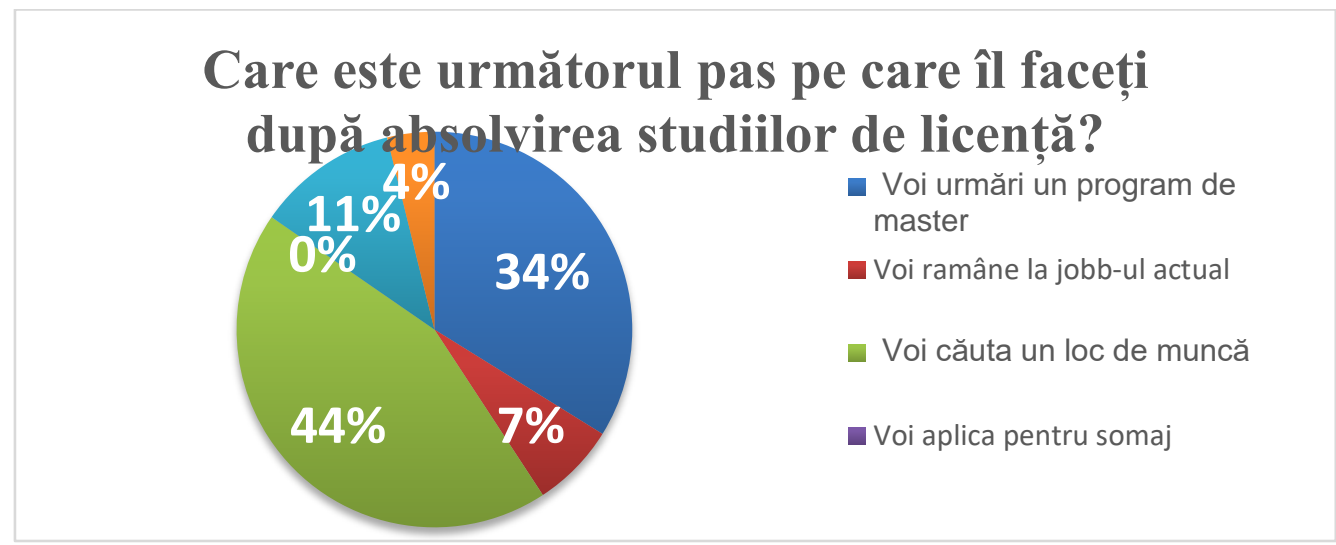

Graficul nr. 19. Parcursul în carieră după absolvirea ciclului de licență

Sursa: Date obținute în urma centralizării rezultatelor pe baza chestionarului aplicat on-line la adresa https://docs.google.com/forms/u/0/ 
Interesant este faptul că un procent de $44 \%$ s-a înregistrat din partea studenților care au răspuns că vor să se angajeze după finalizarea studiilor de licență. Tot cu un procent destul de ridicat se remarcă şi varianta urmării unui program de master, pe când 11 respondenți nu au luat în calcul nicio variant, fiind nehotărâți în momentul completării chestionarului. Cei care muncesc deja spun că vor rămâne la locul actual de muncă (7 respondenți), iar 4\% au ales să răspundă cu propria lor variantă, spre exemplu aceea a inițierii unei afaceri personale sau alegerea de a munci în străinătate.

Următoarea întrebare se referă la motivul pentru care studenții aleg un loc de muncă în afara țării.

Tabelul nr. 21. Motivul pentru care tinerii aleg să muncească în străinătate

\begin{tabular}{|l|l|c|} 
21. & $\begin{array}{l}\text { Care credeți că este motivul pentru care mulți dintre tineri } \\
\text { optează pentru un post de muncă în afara țării în schimbul } \\
\text { celor din județul Suceava? }\end{array}$ & $\mathbf{1 0 0} \%$ \\
\hline & În principal salariul este mult mai atractiv & $82 \%$ \\
\hline & Condiţii mai favorabile de muncă & $5 \%$ \\
\hline & Sunt în căutare de noi experiențe & $2 \%$ \\
\hline & Piața muncii nu corespunde cu aşteptările tinerilor & $10 \%$ \\
\hline & Nu ştiu/ Nu răspund & $1 \%$ \\
\hline & TOTAL & $100 \%$ \\
\hline
\end{tabular}

Sursa: Date obținute în urma centralizării rezultatelor pe baza chestionarului aplicat on-line la adresa https://docs.google.com/forms/u/0/ 


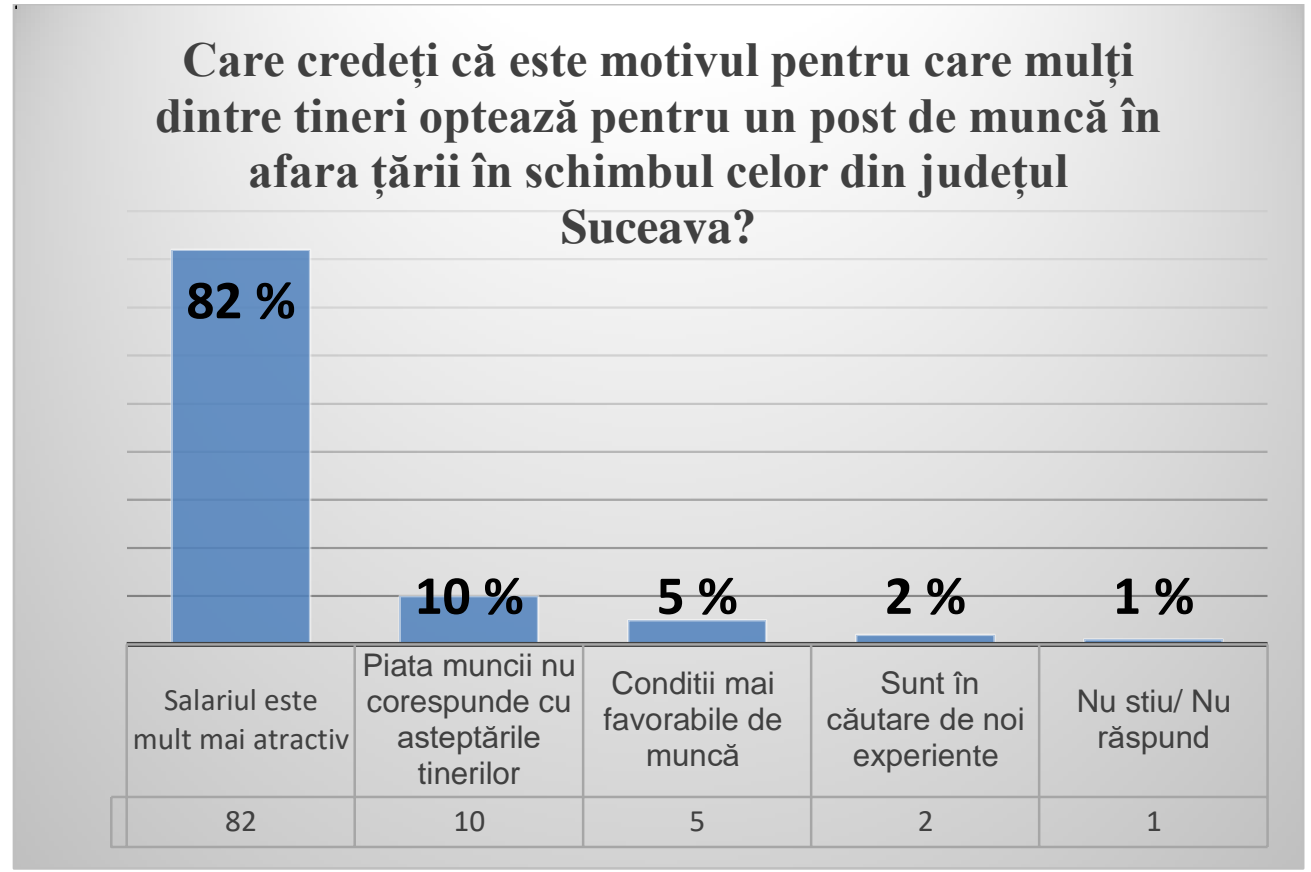

Graficul nr. 20. Motivul pentru care tinerii aleg să muncească în străinătate

Sursa: Date obținute în urma centralizării rezultatelor pe baza chestionarului aplicat on-line la adresa https://docs.google.com/forms/u/0/

Principalul factor care îi determină pe tineri să se angajeze în afara țării în loc să opteze pentru locurile de muncă din județul Suceava este salariul mai atractiv, această variantă de răspuns acumulând un procent crescut, de $82 \%$. Pe lângă acest motiv de bază s-au mai înregistrat răspunsuri şi la celelalte variante, condițiile de muncă fiind indicate într-un procent de 5\%, acumularea de experiențe noi într-un procent de $2 \%$, iar faptul că aşteptările de pe piața muncii suceavene nu corespund cu nevoile studențior a cumulat un procent de $10 \%$.

Corelând întrebarea aceasta cu întrebarea numărul 9, putem constata o asemănare între răspunsurile studenților. Atât în țară (în Suceava), cât şi în străinătate, majoritatea tinerilor care îşi doresc pe viitor să se angajeze are ca motivație principală necesitățile financiare (în formularea din chestionarul nostru, salariul mai atractiv).

Prin această întrebare dorim să aflăm concret unde vor dori studenții să muncească după finalizarea studiilor. 
Tabelul nr. 22. Unde vor muncii tinerii în viitor

\begin{tabular}{|l|l|c|}
\hline 22. & Unde v-ați vedea muncind în viitorul apropiat? & $\mathbf{1 0 0} \%$ \\
\hline & În țară & $65 \%$ \\
\hline & În afara țării & $35 \%$ \\
\hline & TOTAL & $100 \%$ \\
\hline
\end{tabular}

Sursa: Date obținute în urma centralizării rezultatelor pe baza chestionarului aplicat on-line la adresa https://docs.google.com/forms/u/0/

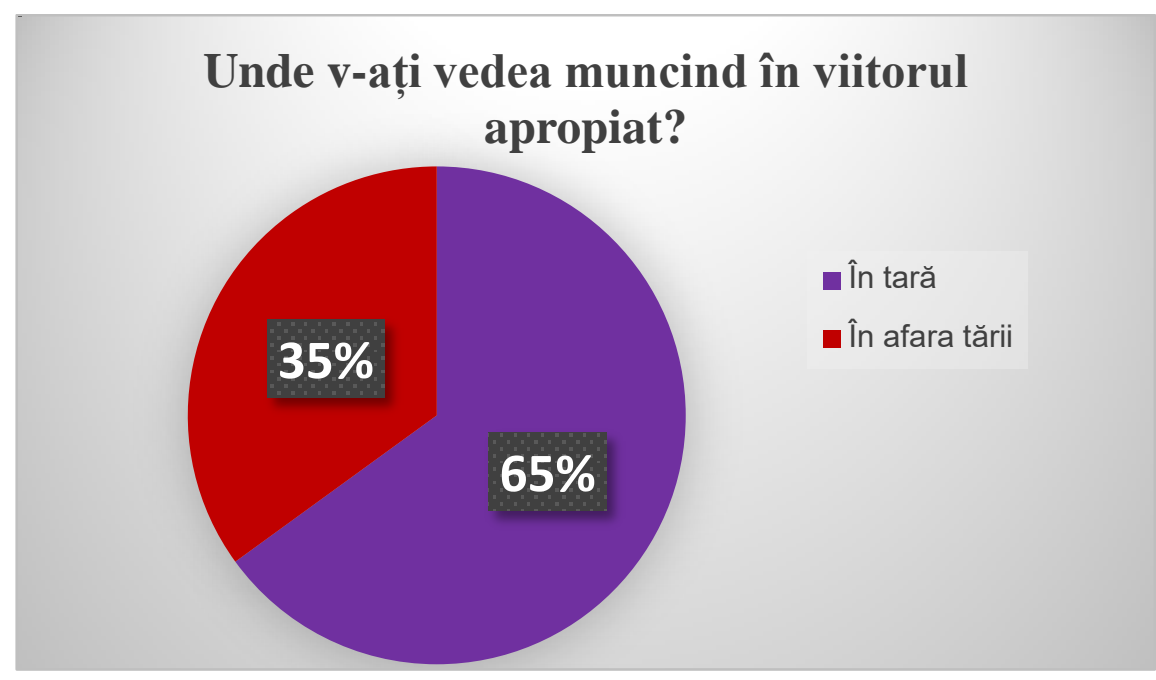

Graficul nr. 21. Unde vor muncii tinerii în viitor

Sursa: Date obținute în urma centralizării rezultatelor pe baza chestionarului aplicat on-line la adresa https://docs.google.com/forms/u/0/

Dacă la întrebarea anterioară studenții sunt de părere că tinerii aleg să muncească în străinătate datorită remunerației mai favorabile, în acest caz, studenții de la USV aleg să muncească pe viitor în țară, procentul acestei categorii ajugând la $65 \%$.

Cei care optează să muncească în afara țării sunt într-un număr mai redus decât cealaltă categorie, cumulând un procent de 35\%. Considerăm că acest procent este destul de îngrijorător, deoarece dacă dintr-un număr de 100 de studenți, o treime aleg să plece în strainittate, putem presupune că procentul înregistrat la nivelul întregii facultăți va fi cel puțin la fel de mare. 
Integration into the Labor Market of Young Students from the "Stefan cel Mare" ... Alexandra TERLEKI

$\mathrm{Cu}$ ajutorul întrebării numărul 23 dorim să aflăm care este părerea studenților în ceea ce priveşte corespondența între situaţia actuală şi aşteptările pe care le-au avut înainte de a începe cursurile.

Tabelul nr. 23. Corespondenţa între situația profesională actuală şi aşteptările avute înainte de începerea studiilor față de locul de muncă

\begin{tabular}{|l|l|c|}
\hline 23. & $\begin{array}{l}\text { În ce măsură corespund aşteptările pe care le-ați avut } \\
\text { înainte de începerea studiilor şi cele din prezent vizavi } \\
\text { de angajare? }\end{array}$ & $\mathbf{1 0 0}$ \% \\
\hline & În foarte mare măsură & $5 \%$ \\
\hline & In mare măsură & $14 \%$ \\
\hline & Nici în mică, nici în mare măsură & $50 \%$ \\
\hline & In mică măsură & $17 \%$ \\
\hline & În foarte mică măsură & $14 \%$ \\
\hline & TOTAL & $100 \%$ \\
\hline
\end{tabular}

Sursa: Date obținute în urma centralizării rezultatelor pe baza chestionarului aplicat on-line la adresa https://docs.google.com/forms/u/0/

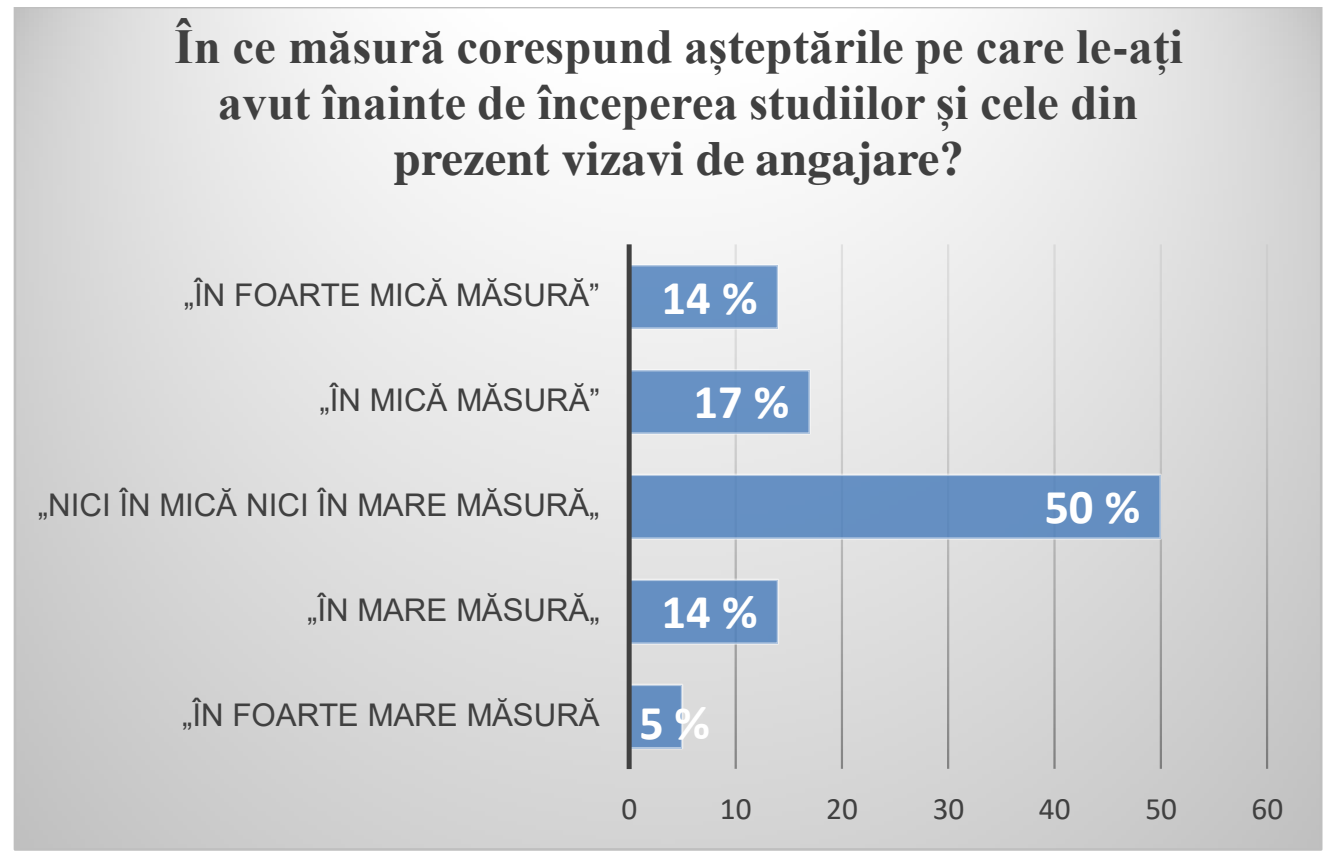

Graficul nr. 22. Corespondența între situația profesională actuală şi aşteptările avute înainte de începerea studiilor față de locul de muncă

Sursa: Date obținute în urma centralizării rezultatelor pe baza chestionarului aplicat on-line la adresa https://docs.google.com/forms/u/0/ 
În urma centralizării rezultatelor la această întrebare putem constata că jumătate dintre respondenți (50\%) sunt imparţiali. Următorul procent, de 17\%, a fost al respondenților care consideră că aşteptările pe care le-au avut în momentul începerii studiilor şi părerea din momentul de faţă corespund într-o mică măsură. Interesant de constatat este faptul că cei care au ales varianta ,în foarte mică măsură” şi cei care au răspuns ,în mare măsură” au acumulat un procentaj identic, de 14\%. Tot la această întrebare am identificat şi un număr de 5 persoane care sunt de părere că locul de muncă şi aşteptările avute corespund.

Prin ultima întrebare am dorit să aflăm gradul de mulțumire al studenților despre piaţa forței de muncă din județul Suceava.

Tabelul nr. 24. Mulțumirea/Nemulțumirea studenților privind angajările pe piața forței de muncă din județul Suceava

\begin{tabular}{|l|l|c|}
\hline 24. & $\begin{array}{l}\text { Sunteți mulțumit/ă în general de situația actuală a pieței } \\
\text { forței de muncă din județul Suceava privind angajările, } \\
\text { din postura Dumneavoastră de student? }\end{array}$ & $\mathbf{1 0 0} \%$ \\
\hline & $\mathrm{Da}$ & $13 \%$ \\
\hline $\mathrm{Nu}$ & $87 \%$ \\
\hline $\mathrm{TOTAL}$ & $100 \%$ \\
\hline
\end{tabular}

Sursa: Date obținute în urma centralizării rezultatelor pe baza chestionarului aplicat on-line la adresa https://docs.google.com/forms/u/0/

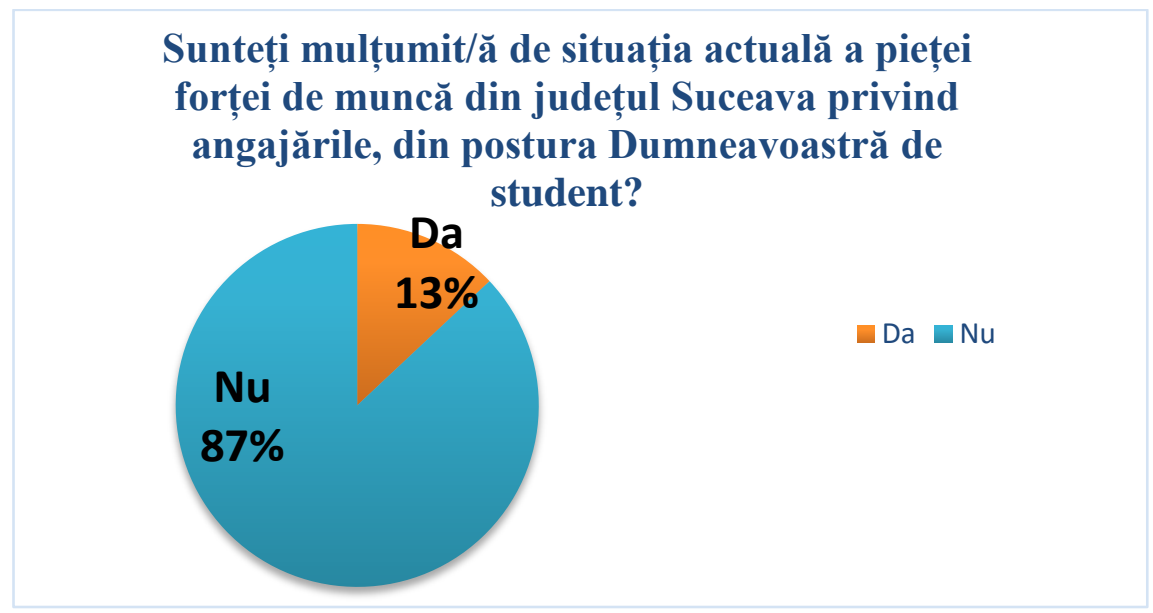

Graficul nr. 23. Mulțumirea/Nemulțumirea studenților privind angajările pe piața forței de muncă din județul Suceava

Sursa: Date obținute în urma centralizării rezultatelor pe baza chestionarului aplicat on-line la adresa https://docs.google.com/forms/u/0/ 
Având în vedere datele obținute la ultima întrebare, se constată o diferență destul de mare între cele două variante de răspuns. Un procent destul de mare nu sunt mulțumiți de felul în care funcționează angajările în județul Suceava $(87 \%)$, iar cei mulțumiți în urma colectării răspunsurilor au adunat un procent de $13 \%$.

\section{Concluzii ale cercetării}

În urma analizei răspunsurilor oferite de studenți am reuşit să desprindem o serie de concluzii asupra percepției studenţilor privind piaţa muncii, importanța programului de licență pentru viitor, ponderea studenților angajați şi imaginea lor despre găsirea unui loc de muncă, gradul de satisfacție oferit de piaţa forței de muncă din Suceava, dar şi altele.

Prin urmare, putem constata că majoritatea studenților au ales să urmeze un program de licență pentru ca prin cunoştințele dobândite să să se poată integra mai uşor în viitor la un loc de muncă, dezvoltându-şi o carieră pe termen lung. De asemenea, am remarcat că majoritatea studenților nu sunt angajați, deşi îşi doresc (datorită diferitelor nevoi financiare), însă motivul principal care îi împiedică este imposibilitatea corelării la nivelul factorului timp a orelor de cursuri cu orele de muncă.

Există şi studenţi care au reuşit să facă faţă programului încărcat, astfel că aproximativ un sfert dintre aceştia s-au angajat, însă în ceea ce priveşte corelarea dintre nivelul de instruire şi ocupația desfăşurată se observă o suprapunere de doar 39\%.

Datele susțin că studenții care au dorit să muncească s-au confruntat cu refuzul angajatorului de a-i angaja deoarece nu aveau experiența necesară pentru locul de muncă respectiv. Prin urmare, studenții care au început de timpuriu să lucreze au avut un avantaj în uşurința găsirii unui job convenabil după finalizarea studiilor faţă de cei care nu au avut încă un contract de muncă.

De remarcat este faptul că studenţii de astăzi sunt adepții mediului online, de unde preiau informații în privinţa posturilor vacante, astfel încât presa scrisă sau anunţurile în ziar nu se mai află sub sfera de intereas a studenților. De asemenea, şi Agențiile pentru Ocuparea Forței de Muncă au fost înlocuite de anunțurile aflate prin intermediul celor apropiați, prietenilor sau cunoscuților.

În urma confruntării cu lipsa locurilor de muncă, studenții sunt de părere că statul ar trebui să le asigure un loc de muncă în funcție de nivelul şi domeniul de studii finalizate. Tot din cauza lipsei locurilor de muncă şi a neconcordanței dintre aşteptările avute de la piaţa forței de muncă sucevene şi realitate, studenții spun în procent de $82 \%$ că aleg să muncească pe teritoriul altei țări, atraşi fiind de avantajele financiare. 
În ciuda faptului că gradul de mulțumire al studenților față de ofertele pieței muncii este redus, ceea ce ne bucură în final este faptul că peste două treimi dintre aceştia $(65 \%)$ ar fi dispuşi să muncească în România, alături de familii şi cei dragi.

În momentul de față putem spune că prin datele colectate de la subiecți şi interpretările realizate pe baza acestora, obiectivele cercetării au fost atinse, precum şi scopul, reuşind astfel să ne formăm o părere despre gradul de mulțumire al studenților de la Universitatea "Ştefan cel Mare" din Suceava în ceea ce piveşte angajarea şi disponibilitatea de locurilor de muncă din județul Suceava.

\section{Acknowledgement}

Articolul a fost extras din cercetarea aplicativă desfăşurată în cadrul lucrării de licență susținută în cadrul Universității Ştefan cel Mare din Suceava, cercetarea fiind realizată sub coordonarea ştiințifică a Prof. Univ. Dr Antonio SANDU.

\section{Bibliografie}

Chestionar privind modul de integrare pe piaţa muncii al tinerilor studenți din cadrul Universităţii „SStefan cel Mare” din Suceava. (2018). Disponibil la https://docs.google.com/forms/d/1zLJ0mzX3FNDieOYwau1bhcmcXd2jf OcvIJ94JW8LCcc/edit

Universitatea „SStefan cel Mare” din Suceava (USV). (2017). Raport privind starea universităţii. Disponibil la http://www.usv.ro/fisiere_utilizator/file/Acte\%20oficiale/2018/Raport\%20

Rector\%20USV_\%202017.pdf 